Article

\title{
Economies of Scale and Perceived Corruption in Natural Resource Management: A Comparative Study between Ukraine, Romania, and Iceland
}

\author{
Johanna Gisladottir ${ }^{1,2,3, *}$, Sigurbjörg Sigurgeirsdottir ${ }^{1}$, Kristín Vala Ragnarsdóttir ${ }^{2}$ and Ingrid Stjernquist ${ }^{3}$ \\ 1 Faculty of Political Science, University of Iceland, 102 Reykjavik, Iceland; silla@hi.is \\ 2 Institute of Earth Sciences, University of Iceland, 102 Reykjavik, Iceland; vala@hi.is \\ 3 Department of Physical Geography, Stockholm University, 10691 Stockholm, Sweden; \\ ingrid.stjernquist@natgeo.su.se \\ * Correspondence: jog31@hi.is
}

check for

updates

Citation: Gisladottir, J.; Sigurgeirsdottir,

S.; Ragnarsdóttir, K.V.; Stjernquist, I.

Economies of Scale and Perceived

Corruption in Natural Resource

Management: A Comparative Study between Ukraine, Romania, and Iceland. Sustainability 2021, 13, 7363. https://doi.org/10.3390/su13137363

Academic Editors: Francesco Riccioli and Mario Cozzi

Received: 30 April 2021

Accepted: 25 June 2021

Published: 30 June 2021

Publisher's Note: MDPI stays neutral with regard to jurisdictional claims in published maps and institutional affiliations.

Copyright: (c) 2021 by the authors. Licensee MDPI, Basel, Switzerland. This article is an open access article distributed under the terms and conditions of the Creative Commons Attribution (CC BY) license (https:/ / creativecommons.org/licenses/by/ $4.0 /)$.

\begin{abstract}
The aim of this paper is to enhance understanding of factors that undermine sustainable management of renewable resources by identifying and analyzing the main drivers and dynamics involved, with a focus on the role of corruption perceptions and its implications. To shed light on the research question, we chose to perform a comparative study of three different resource sectors in European countries that are ranked differently on the Corruption Perception Index by Transparency International, namely fisheries in Iceland, forestry in Romania, and arable soils in Ukraine. We conducted 40 in-depth semi-structured interviews with various stakeholders to explore assumptions on individual actions and behavior in the sectors. The interviews were analyzed using a qualitative coding procedure based on causal loop diagrams, a method from system dynamics. The results indicate that even though the cases are different, they share a similar outcome, in that privatization of the resource and consolidation of companies took place, along with perceived risk of both unsustainable resource management practices and corruption. Our findings suggest that the underlying similarities of the cases are that privatization occurred around the same time in early 1990s, when neoliberal economic ideology influentially held up the idea that private ownership meant better management. What followed was a transition to economies of scale that ultimately resulted in dominance of large vertically integrated companies in the sectors. The resulting inequalities between large and small actors in the renewable resource management systems serve to increase the risk for unsustainable management decisions as well as increase perceptions of corruption risks, especially amongst smaller actors in the sectors.
\end{abstract}

Keywords: renewable natural resources; corruption; resource management; sustainability

\section{Introduction}

The current climate crisis has highlighted the need to advance knowledge of the mechanisms contributing to sustainable natural resource management. As a part of such an endeavor, more effort needs to be directed toward the understanding and mapping of drivers behind the unsustainable use of resources, especially since the growing population is projected to be associated with growth in resource use [1,2]. Challenging the "Tragedy of the Commons" arguments [3], Elinor Ostrom [4] has influentially covered the topic and associated problems of many individuals collectively attempting to organize productive use of natural resource systems while ensuring their long-term sustainability. A commonly used economic instrument to alleviate collective action problems associated with resource use has been to assign property rights to resources, which are then meant to generate economic incentives to influence behavior toward better management [5].

Agriculture, forestry, and fisheries have been recognized as key sectors for realizing the circular bioeconomy of well-being [6] and their importance for sustainable development [7]. 
To further highlight the importance of the food and agriculture sectors, it is noted that they are the cornerstones of the 2030 Agenda for Sustainable Development, whereas they have been linked to 14 out of the 17 Sustainable Development Goals (SDGs) [8]. According to the Food and Agriculture Organization of the United Nations (FAO), good governance is the key to ensuring sustainability in the agriculture, forestry, and fisheries sectors when it is built on integration and harmony with environmental integrity, economic resilience, and social well-being [9].

Due to the high level of revenues that usually characterizes resource sectors, they can be particularly prone to experiencing corruption, which can undermine resource management policies $[10,11]$. There is no universally accepted definition of corruption, but the most commonly used definition is the one put forward by Transparency International, which is "the abuse of entrusted power for private gain" [12]. In a natural resource context, Robbins [13] views corruption as alternative norms rather than an absence of rules and states that, when simply put, it equals "common property management gone bad". He further defines it as "the use or overuse of community (state, village, city, etc.) natural resources with the consent of a state agent by those not legally entitled to it". However, in the context of fisheries, Sumaila et al. [14] have pointed out that the definition of corruption has extended beyond the public sector, as they define it as acts of cheating at the hand of individuals or larger entities that act in an illegal manner that serves to undermine the resource itself, as well as responsible local stewardship of it. Apart from the definition of the term, there are also different ways scientists conceptualize, measure, and consider corruption as a phenomenon. The main strands of the academic debate on the phenomenon center around viewing corruption as a collective action problem $[15,16]$ or applying the principal-agent approach to study corruption $[17,18]$. The former takes the viewpoint that an individual's actions and behavior are shaped by what they anticipate of others as well as their expectations of the consequences for their actions [16]. The principal-agent approach views agents as actors, or a group of actors, that takes an action or a decision on behalf of another actor or group of actors, namely the principal [19]. The principal thus entrusts the agent with power and sets rules to influence how the agent fulfils the tasks [17]. The agent can for example be an elected official that is supposed to make decisions regarding resource allocation, based on the interests of the principal—the public — and not their own [20].

The aim of our research is to identify the main drivers and dynamics contributing to unsustainable resource management practices and the role that corruption plays in that context. In that endeavor, we seek to gain an understanding of the perceptions and motivations of individual actors that have a stake in three resource sectors as well as the implications. We believe our findings will contribute to the ongoing academic discussion of context-specific corruption dynamics and sustainable natural resource management. Additionally, they serve to inform policymakers about where attention should be directed when designing solutions to tackle unsustainable management practices and promote long-term thinking.

\section{Materials and Methods}

\subsection{Case Study Approach}

A comparative qualitative case study design was chosen to set a boundary and a scope to the research. The analysis was based on Ragin's approach to case-oriented inquiry, namely his simple paradox resolution in which $A$ and $B$ are different, yet they experience similar outcomes [21]. In our research, the simple paradox resolution takes the form of A and $\mathrm{B}$ and $\mathrm{C}$ are different, yet they experience similar outcomes. By applying this approach, we are not testing hypotheses, but seek to explore and describe what causally relevant similarities between these different cases might explain a common outcome.

\subsection{Case Study Selection}

The case selection was based on the need to make compromises between what was feasible and what was desirable [22] without compromising the possibilities to maximize 
learning and enhanced understanding of the subject matter [23]. A multiple and comparative case study design was chosen since it provides a more robust and compelling basis for the research outcomes as the ambition was to draw generalizations from the findings, despite limitations. We wanted to select countries that had varied ranking on corruption levels on the Corruption Perceptions Index (CPI) by Transparency International. The authors had connections in Iceland, Romania, and Ukraine, which served to limit the resources needed for the fieldwork. The countries ranking on the CPI also varied. The decision was made to focus on the arable land soils in Ukraine, forestry in Romania, and fisheries in Iceland. The reason for choosing different resource sectors for each country was that the results should provide general lessons on renewable resource management challenges, not just on fisheries management, soil, or forestry alone. These resources are also important for each respective national economy as well as being highly valued in a cultural and historical sense.

As demonstrated in Table 1, Ragin's simple paradox resolution for our three cases will take the form that Iceland, Romania, and Ukraine are different, yet they experience similar outcomes.

Table 1. Simple paradox resolution and the comparison between Iceland, Romania, and Ukraine.

\begin{tabular}{|c|c|c|}
\hline Main Differences & Similarities & Similar Outcomes \\
\hline Population size and density & & Privatization of natural resource \\
\hline Economic development & & $\begin{array}{l}\text { Consolidation of companies in } \\
\text { the natural resource sectors }\end{array}$ \\
\hline Degree of European integration & & $\begin{array}{l}\text { Perceived risks of unsustainable } \\
\text { resource management practices }\end{array}$ \\
\hline Ranking on the CPI & & Perceived corruption risks in resource sectors \\
\hline
\end{tabular}

The main differences between the cases are that they vary in terms of population size and density. Iceland is inhabited by 360 thousand people with a population density of 3 people per $\mathrm{km} 2$ of land area while the corresponding numbers for Romania are 19.3 million people with a density of 85 , and 44,3 million people with a population density of 77 in Ukraine [24,25]. Their ranking on the CPI varies, but Iceland was ranked 11th, Romania 70th, and Ukraine 126th out of 180 countries on the list in 2019 [26]. The lower a country's score on the list, the more corruption is considered to be in place. The degree of European integration varies, as Romania is a member of the EU, Iceland is a member of the EEA, while Ukraine is neither. Gross national income per capita can serve as an indicator of the variation in economic development between the countries, which was 73.000 US\$ in Iceland in 2019, with the corresponding numbers being 12.620 US\$ in Romania and 3.370 US\$ in Ukraine [27]. Similar outcomes are that in all three cases, ownership of the natural resource shifted toward privatization, consolidation of companies have occurred, and interviewees perceived both a risk of unsustainable resource management practices as well as corruption risks in all cases, despite the different rankings on the CPI. Our exercise is to trace what possible underlying similarities, or combination of conditions, could explain the similar outcomes.

\subsection{Methods of Data Collection}

In an effort to study assumptions and perceptions of the motivations that shape individual actions within the sectors, the method of semi-structured interviews with various stakeholders was considered appropriate. After setting the scope and boundary of the research, we sought and were granted a reference for the fieldwork from the Research Ethics Committee of University of Iceland in late 2017. An understanding of each management system was then developed through constructing stakeholder maps, dividing them into either stakeholders along the value chain such as farmers and business owners or as value chain influencers and enablers, such as decision makers, journalists, and academics [28-30]. Following that, 2-3 key informants were recruited and interviewed in each case, based on the selection criteria that they (1) did not belong to the same stakeholder group or network 
and (2) were believed to be highly knowledgeable about the sector. The latter criteria served the purpose of gaining insights into the sectors as well as ensuring they could easily suggest additional participants, as further recruitment of interviewees was gathered through snowball sampling [31], partly based on the critically examined lists of suggestions provided by the key informants. The interviews were 40 in total, and conducted in person in Iceland, Romania, and Ukraine in 2018, with the exception of two that were conducted via skype or phone. They were taken after informed consent had been obtained, generally lasted for $1 \mathrm{~h}$, and were conducted in Icelandic, English, Romanian, or Ukrainian, with a translator present when conducted in the latter two languages. A questionnaire with open-ended questions was used to navigate the interviews, for example, regarding how the resource management system worked, their experience and perceptions on how decisions are taken along the value chain, trust between stakeholders, the media environment, their view on democratic development in their countries, and where corruption risks in the system could be located. Follow-up questions were asked if there was a need for further detail or clarifications. Special precautions were taken to ensure anonymity of all interviewees, due to the politically sensitive nature of the topic under study. Based on the stakeholder map, attention was paid to having representatives with various employment positions in the study, as well as having a balance between age groups, gender, and urban/rural residence. Table 2 provides an overview of the stakeholders, where it is not specified whether they currently or formerly held the position in order to further protect their anonymity.

Table 2. Overview over stakeholders interviewed for the research.

\begin{tabular}{|c|c|c|c|}
\hline Stakeholder Category & Ukraine & Romania & Iceland \\
\hline Current/former NGO staff/member & 8 & 5 & 2 \\
\hline Current/former resource owner/recipient & 1 & 2 & 2 \\
\hline Current/former Member of Parliament & 1 & 1 & 2 \\
\hline Current/former journalist & 1 & 1 & 1 \\
\hline Current/former parliamentary staff & 1 & 1 & 1 \\
\hline Current/former member of academia & 3 & 3 & 3 \\
\hline Current/former public official & 7 & 3 & 4 \\
\hline Current/former member of government & 1 & 0 & 0 \\
\hline $\begin{array}{r}\text { Current/former representative from harvesting } \\
\text { operations/exploitation of resource }\end{array}$ & 2 & 4 & 5 \\
\hline Current/former small business owner & 3 & 1 & 1 \\
\hline Current/former big industry worker & 0 & 1 & 2 \\
\hline Current/former local politician & 0 & 0 & 1 \\
\hline Current/former employee in the finance sector & 1 & 0 & 1 \\
\hline Total Interviews & 15 & 13 & 12 \\
\hline $\begin{array}{l}\text { Total Participants } \\
\text { Of those: }\end{array}$ & 17 & 15 & 12 \\
\hline Number of female participants & 4 & 1 & 3 \\
\hline Number of male participants & 13 & 14 & 9 \\
\hline Age $20-40$ years & 5 & 5 & 2 \\
\hline Age $40-60$ years & 6 & 6 & 5 \\
\hline Age $60-80$ years & 6 & 4 & 5 \\
\hline
\end{tabular}

${ }_{1}^{1}$ On a few occasions, interviewees showed up to the interview with a partner/colleague and both took part in the interview.

Many interviewees could be positioned in more than one category, since they had held different roles in the sector. They were placed in all the categories that applied to them. As a result, when the numbers from each stakeholder category are added up, they exceed the total number of the interviewees. This has been done to demonstrate that the background of stakeholders that took part in the study is broad, as when interviewees answered the open-ended questions, they would often reflect on past experiences when they had served more than one role in the sector.

A balance between male and female representation among stakeholders was not reached, as females were more reluctant to give an interview, often citing time constraints or lack of knowledge. We were also unsuccessful in ensuring interviews with current or former owners of large companies in each sector, which creates a limitation when interpreting the findings of this study. 


\subsection{Data Analysis}

Ragin [21] states that the patterns that emerge from the behavior of social systems are derived from structural processes that occur due to the structural features in place and their interrelations [21]. The interview data were analyzed through qualitative coding methods [32], as well as methods originating in systems thinking, which is a view or a lens that provides us with the abilities to understand behavior patterns $[33,34]$. System dynamics comes from within the greater field of systems thinking, where it can be described as one of the methods seeking to enhance understanding and learning in complex systems [34,35]. So-called causal loop diagrams (CLDs) are used in system dynamics and are in their essence a method for qualitative mapping that generates insights into both structural properties of systems as well as presumed actor's behavior, based on mental models [34]. Mental models of dynamic systems is a central term in the field and can be defined as "a relatively enduring and accessible, but limited, internal conceptual representation of an external system whose structure maintains the perceived structure of that system" [36] (p. 19). It is a way of elucidating feedback causality behavior [37] and enables us to conduct a systemic analysis of variables and their interconnections that come up during this research. This will enrich our understanding of the resource sectors and what the stakeholders assume motivates individual actions within them and complements Ragin's comparative approach of simple paradox resolution. The approach of using CLDs facilitates the exploration of which underlying factors are causally relevant for explaining the similar outcome.

The interview data acquired through conduction of the interviews were first transcribed and then processed in the software NVivo to manage the collected texts and transcripts from the interviews. Codes were assigned to the data that were then sorted into themes. To provide an example, "transition to economies of scale" was identified as a theme, and "access to finance" one of its sub-codes. This process provided the opportunity to understand the data and how a narrative could be built within the emerging themes. The next step consisted of coding the data for generating CLDs. When doing so, there is a need to establish a traceable link between the diagram and the data [38]. A coding procedure was therefore developed, based on the work of Turner, Kim, and Andersen in addition to Spicer, which is influenced by grounded theory [38-41]. Each variable and their relationships were listed in Excel as identified by interviewees, as well as the background information on each stakeholder, to allow to an iterative process of analysis between the interviews and the CLDs. To provide an example, the following quote: "So, in the first several years after the quota system, you saw this massive selling of these smaller amounts of quota, and then quota accumulating to the people that already have had larger amounts, were therefore making more money off the fishery, and could therefore buy more quota" would be coded as demonstrated in Table 3 below.

Table 3. Example of the qualitative causal map procedure stage conducted in Excel.

\begin{tabular}{|c|c|c|c|c|c|c|c|c|}
\hline 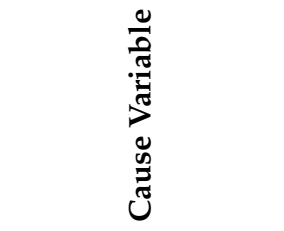 & 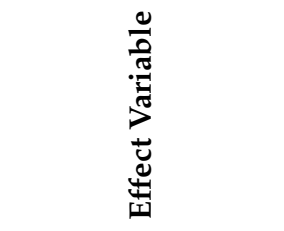 & 预 & $\underset{\Xi}{\Xi}$ & 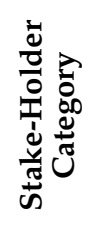 & 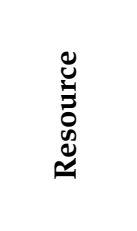 & 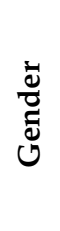 & $\underset{\infty}{4}$ & : \\
\hline $\begin{array}{l}\text { Ability to buy } \\
\text { more quota }\end{array}$ & Quota bought & + & Iceland & $x$ & Fisheries & $\mathrm{x}$ & $x$ & $\mathrm{x}$ \\
\hline Quota bought & Size of quota shares & + & Iceland & $\mathrm{x}$ & Fisheries & $\mathrm{x}$ & $x$ & $x$ \\
\hline Size of quota shares & Access to capital & + & Iceland & $x$ & Fisheries & $\mathrm{x}$ & $x$ & $x$ \\
\hline Access to capital & $\begin{array}{l}\text { Ability to buy } \\
\text { more quota }\end{array}$ & + & Iceland & $\mathrm{x}$ & Fisheries & $x$ & $\mathrm{x}$ & $\mathrm{x}$ \\
\hline
\end{tabular}

After all the interviews had been coded into Excel according to this method, the variables and the relationships were moved over to a system dynamics software tool, Vensim, to construct CLDs of each case. The interviewee in this instance is describing 
a reinforcing loop, which would then be represented in the following structure seen in Figure 1.

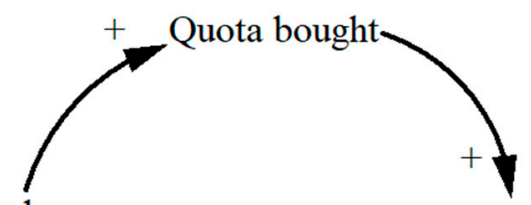

Ability to buy more

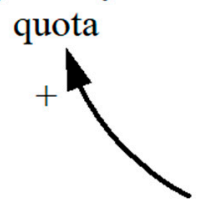

Size of quota

$\mathbf{R}$ shares

Access to capital

Figure 1. An example of a causal loop diagram.

The way to read a CLD is to start with a variable and trace it through the loop by following the direction of the arrows. The arrow denotes the nature of the interaction between two variables. If an arrow has a plus sign, it means that a change in the first variable will lead to a change in the same direction of the second variable (the more- the more/the less-the less). If the polarity of the relationship is negative, the change occurs in the opposite direction (the more-the less, or vice versa). When negative polarities between relationships in a loop are counted, and they add to an even number, the loop is reinforcing, represented by the letter " $R$ " in the figure. The same applies if the loop only contains positive polarities. If the number of minuses is odd, it is a balancing/counteracting one, represented by the letter " $\mathrm{B}$ " [35].

When all coding had been finalized, CLDs were drawn up through an iterative process to ensure that the feedback structure captured in Vensim corresponded to the interview text. The final CLDs are simplified portrayals of collective mental models, constructed from the causal structures and assumptions of their relations as identified by individual interviewees. The last stage was then to compare the CLDs in accordance with Ragin's approach of uncovering underlying similarities. Feedback on the results was then sought from translators and key informants. A limitation to this work is that since all the interviews were conducted and coded by the lead author of the study, it introduces the possibility for greater bias in the research, as interpretations and assumptions play a role in the coding process $[38,40]$.

\section{Results}

\subsection{Arable Land Ownership in Ukraine}

Ukraine is often referred to as the breadbasket of Europe since it enjoys thick black soils high in organic matter content, known as chernozems, but it occupies approximately half of the country, or $68 \%$ of all arable land [42]. The fertility level of the soils in Ukraine does not solely play a role for the national economy, but it has a global relevance since the country is a major exporter of agriculture products [43]. Natural processes influence soil fertility through, for example, wind and water erosion, but accelerated soil erosion is the result of land cultivation approaches, and that is where human decision making becomes important [44]. According to a press release by the FAO in 2018, when kicking off a project to combat land degradation in the country, it is estimated that degraded and unproductive arable land in Ukraine covers over 6.5 million hectares, annual loss of soils due to erosion is between 300 to 600 million tons, and reduction in crop yield due to degradation can translate into billions of Ukrainian hryvnias [45]. The annual value of eroded soils translates into a third of the agricultural gross domestic product [42].

Land in Ukraine was monopolized by the state in 1917, and agriculture was practiced on collective state-owned farms. After Ukraine declared independence in 1991, land reform was launched with the aim of transforming the agriculture sector "into a more efficient and 
productive system based on market principles and private ownership" [46]. Land that had previously been cultivated by collective farms during communist times was privatized and distributed among the eligible population in the 1990s [47]. The average land size given to an individual was about 3-5 hectares, but as each individual only received a certificate stating personal information about the owner and the size of the land, without specifying the exact location of that land, people were not able to cultivate the land and opted for leasing their land collectively to larger actors [47]. As a response to that problem, the cadastre gradually replaced certificates with ones that specified the location as well as the size [47]. According to Stupak [44], the widely held belief that private ownership of a resource contributes to better management of it, which has been supported in empirical studies, does not appear to apply in the case of Ukraine, as soils have continued to degrade after privatization $[42,44]$.

Interviewees explained that there had been concerns that rich people would be able to buy up all the land in Ukraine due to the low-income status of most of the new landowners, and land grabbing would occur. Therefore, a ban of sale of land was put in place in the early 1990s, referred to as the land moratorium [47]. The idea was that proper reforms to the legislation needed to be put in place before a market for land could be opened, and the ban has been prolonged several times. Whether or not the country should lift the land moratorium has been subject to a fierce debate in the Ukraine [46], and one of the interviewees for this research described the topic as politically toxic. However, according to a recent land reform law, a market for agricultural land is planned to open in July 2021 [48]. It became apparent in the interviews that even though this research was aimed at soil management, the issue of land moratorium could not be separated from the topic, since the two are interlinked.

\subsubsection{Consolidation of Companies in the Agriculture Sector}

Through the process of restructuring the agriculture sector after 1991, the reform essentially led to a dual structure consisting of large scale farming on one hand and small scale on the other [47]. The latter usually own a piece of agricultural land and lease additional land, whereas the average farmer uses below 500 hectares of land, with a majority using less than 50 ha [45]. At the other end of the scale, we have so-called agroholdings. They are defined as "vertically and horizontally integrated groups of affiliated and associated agroenterprices" [47], which operate with the purpose of maximizing profit and therefore engage in industrial, soil-degrading agriculture [47].

We first explore the identified dynamics that drive consolidation of enterprises in the Ukrainian agriculture sector and the implications of that development for arable soils. Figure 2 addresses that question using a CLD containing three reinforcing feedback loops, namely R1, R2, and R3, and balancing loops B1 and B2.

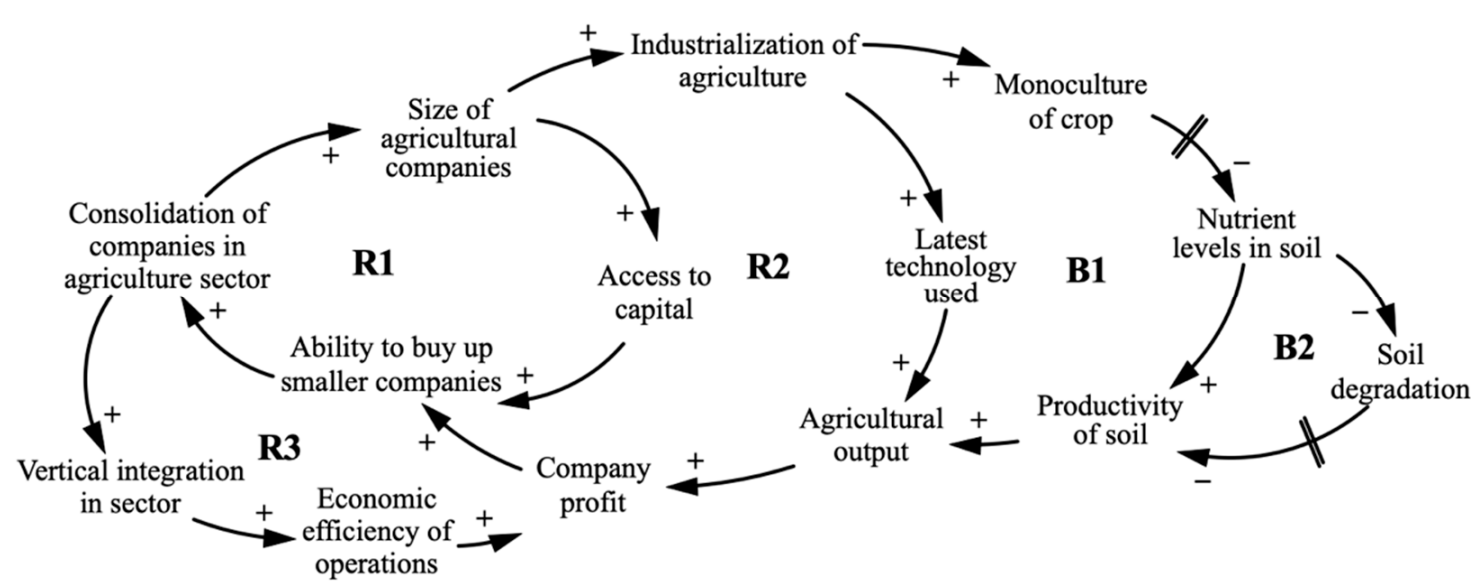

Figure 2. A CLD displaying consolidation of companies in the Ukrainian agriculture sector and its implications. 
We begin by exploring Loop R1 in the diagram through the variable "size of agricultural companies": the larger the size, the more access the company has to capital with low interest rates to invest with. The more access to capital, the more ability there is to buy up other companies, which often have pre-existing lease agreements for land. The more ability there is to buy up other companies, the more consolidation of companies takes place, coming back to further increase the size of the agricultural businesses. In Loop R2, we have a reinforcing cycle, whereas the size of the agriculture business grows and thus accelerates industrialization in the agriculture sector. More industrialization comes with increased use of the latest technology in agricultural operations, which serve to generate more agricultural output. The implications of that industrialization have led to fewer job opportunities in rural areas, as it has become less labor-intensive. Current/former public officials involved in monitoring nutrient levels in soils discussed how agroholdings had their own laboratories and had greater ability to take advantage of the latest science and technology to increase output than those farmers operating on a small scale. More output leads to more profit for the companies, which means their ability to buy up other companies increases, consolidation of companies occurs, and the size of agricultural companies grows. Interviewees also mentioned that as agroholdings bought up smaller companies in the sector, they were increasingly becoming vertically integrated, gaining ownership of the entire value chain as they, for example, owned harvesting machinery, storage facilities, and export companies. This is represented in reinforcing Loop R3, where consolidation of companies leads to enhanced vertical integration, resulting in enhanced economic efficiency of operations, serving to increase company profit, which grants them the ability to buy up more of smaller companies, which in the end comes back to increased consolidation of companies in the agriculture sector.

In exploring the balancing Loops B1 and B2, we begin with the familiar variable of the size of agricultural companies. As they grow, so does the industrialization of agriculture. As industrialization increases, the sector moves more toward monoculture of crops. Several interviewees mentioned that the development in the agriculture sector in Ukraine has been toward producing crops that have short production cycles to maximize the productivity of each harvest, as well as the profits. Cultivation of those crops, however, tends to degrade soils in the long run. As explained by a current/former public official: "They [agroholdings] have land of more than $500,600,800$ thousand hectares. That is obviously a problem since they are doing intensive agricultural work and are taking away the soil resources and exhausting it as they are aimed at monocultural production". Land cultivation in this realm on this scale tends to be production of intensive crops, grown for exporting and the potential for quick profit [43]. A FAO report on soil fertility in Ukraine states that the production of "industrial crops such as sunflower, rape, and soya has grown considerably since the early 1990s" [42]. Sunflower, for example, gained popularity amongst agricultural producers, since high prices combined with low production costs provided high profitability. Official recommendations specify that due to its deep rooting system that extracts a higher amount of nutrients from the soil compared to other crops, risk of fungal diseases, and depletion of soil moisture, the frequency of sunflower in crop rotation should be once every seven years. However, official recommendations of crop rotation are often violated, eventually contributing to monoculture [42]. As a result, nutrient levels in the soil deplete over the long term. This is demonstrated by a delay in the relationship between monoculture and nutrient levels, represented by a dash through the arrow. Soil degradation is the result of a decrease in nutrient levels in the soil, meaning less productivity of soils, which also occurs through a delay. Lower productivity translates into a decrease in agricultural output and less profit, ultimately resulting in a decrease in the size of agricultural businesses. That means that Loops B1 and B2 are due to soil degradation and work to counteract the reinforcing dynamics of company consolidation in Loop s R1, R2, and R3, but as they contain delays and represent long-term development, the reinforcing loops currently dominate the system, which drives the consolidation of companies and soil degradation. 


\subsubsection{Socioeconomic Conditions of Small-Scale Farmers}

We explore the drivers and implications of soil degradation in Ukraine in the context of small-scale farming in the diagram in Figure 3, which is Figure 2 integrated with the dynamics concerning small-scale farming.

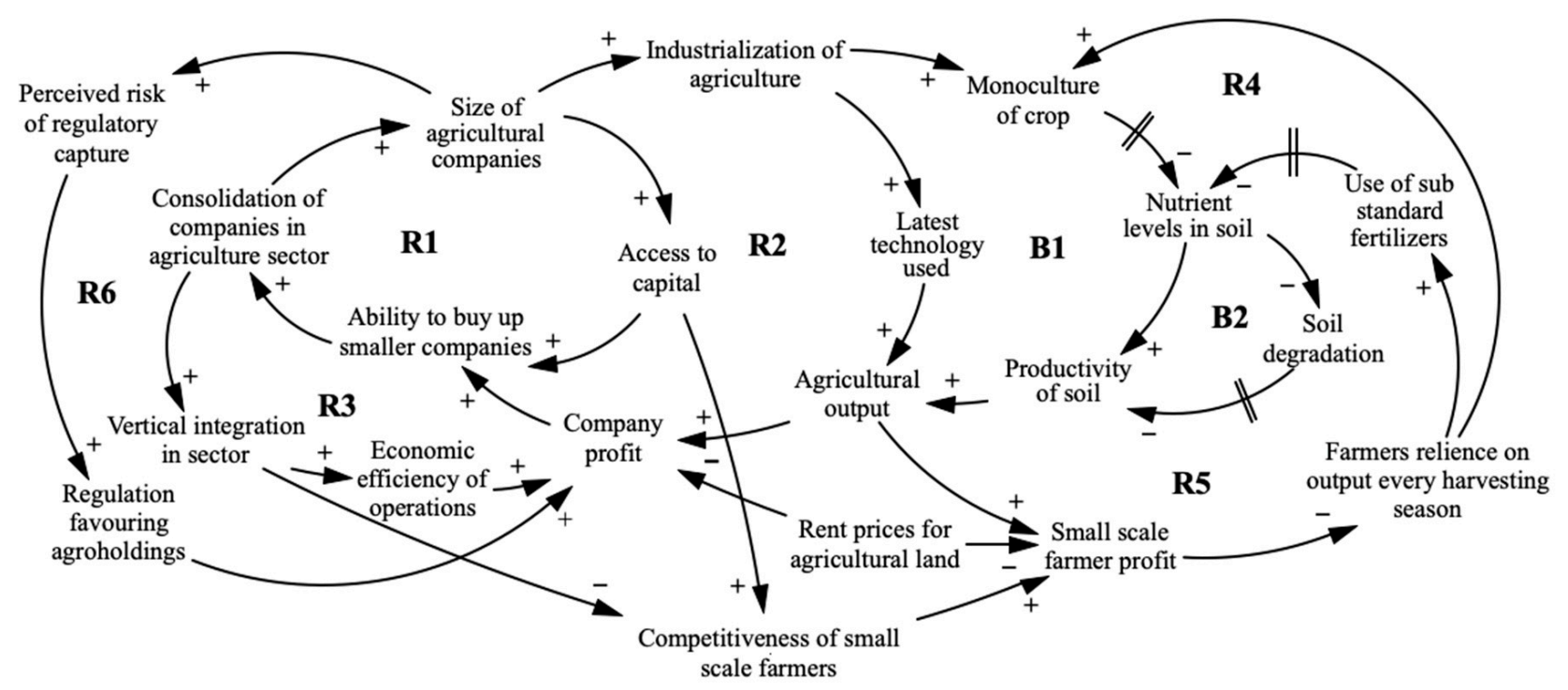

Figure 3. A CLD representing the dynamics driving soil degradation in the context of small-scale farming, integrated from Figure 2.

On the bottom of the figure, we can see that with increased vertical integration in the sector, small-scale farmers are decreasingly competitive in comparison with large vertically integrated agroholdings that have the ability to maximize economic efficiency. Less competitiveness of small-scale farmers means their profit decreases, as they are, for example, not in an as strong a position to negotiate prices as larger companies are. Additionally, rent prices for agricultural land factor into profit accumulation in the sector, disadvantaging small-scale farmers, which can be observed toward the bottom of Figure 3 . To date, owners of agricultural lands are mostly comprised of older individuals or those who have inherited the land and are not necessarily those who cultivate it. Since they are not able to sell their land, they normally lease it out to others for farming, and the leasing price is very low in comparison to internationally [47,49]. Interviewees mentioned low rent prices for agricultural land as a factor in profit accumulation by agroholdings, but as described by a current/former NGO member: "So now, since you cannot sell the land, there is no market for it, and it creates very low price for renting. Which is very good for the large corporations, because they get it for a very low price". A current/former employee of an agricultural exporting company described the vulnerability of small farmers, who are paying for leasing of the land, but enjoy minimal economic security for their operation, as the landowners could potentially take the land back and lease it to someone else, and agroholdings are able to offer higher rent payments. Additionally, as the land small-scale farmers cultivate mainly consists of leased land and not solely their property, they are not able to put the land up as collateral for banking loans. The uncertainty regarding the land moratorium further discourages banks from offering loans to the farmers. This corresponds with findings from Mamonova [43] that many small-scale farmers experience tight economic conditions as they do not have the advantage of bank credits to the same extent as agroholdings. Many interviewees discussed the lack of access to capital for small-scale farmers as a major hindrance for the development of the sector. They were using outdated agricultural machinery, facilities, and irrigation systems, unable to invest in farming infrastructure and newer technology.

We turn our attention to reinforcing Loop R4 and start with the variable of small-scale farmer profit. As profit goes down, farmers' reliance on output every season increases. 
The link was described by a current/former small business owner in the agriculture sector, that farmers "are not interested too much to invest in earth, for example, to leave their fields for one year, for rest, to keep the nutrition elements in the soil. People are just losing money for that. So, currently farmers are interested to earn money every season, and at maximum level". The cost is decreasing nutrition levels in soils, since it promotes a bad practice of monoculture of "really messy crops that farmers are sure they can be able to sell". Monoculture practices decrease nutrient levels in the soil through a delay, which end up reducing the productivity of the soils as well as decreasing agricultural output, which comes back to decrease small-scale farmer profit.

In reinforcing Loop R5, we explore how the use of sub-standard fertilizers drives soil degradation. According to Shikula [50], crop growth has depleted nutrient elements steadily, and moreover, loss in soil fertility means that the production cost of crops grows, since additional resources are needed to maintain the same levels of productivity, for example, through added fertilizers to maintain the same crop yield [42]. We begin by exploring the loop with the variable of small-scale farmer profit. As it declines, farmers reliance on producing agricultural products every harvesting season increases, and their use of sub-standard fertilizer goes up. As described by a current/former small business owner, small-scale farmers can not necessarily afford the chemical fertilizers they perceive they need to use in order to maximize their output. Therefore, instead of using standardized ones, they use low-cost, sub-standard fertilizers on the soils, further exacerbating soil degradation. He stated: "I think that there is quite a big market of grey fertilizers, probably grey fertilizers from China, because not all farmers would like to purchase high-quality fertilizers. Many of them are interested in low price products". This was then confirmed by a current/former farmer, who discussed how small farmers opted for buying the cheaper fertilizer to increase output, but then in a few years, they experienced considerable soil degradation. This was a development they might not be aware of at first, but they ended up going out of business as a result.

According to current/former public officials, there is an absence of legal mechanisms for consequences if arable land soils degrade due to human decision making, and it is unclear whether such mechanisms should be at the hands of the courts or soil inspectors. This serves to complicate the facilitation of sustainable soil management.

Reinforcing Loop R6 on the left side of the diagram represents a common perception among interviewees that as the size of agricultural companies grows, so does the risk of regulatory capture, so that regulations end up favoring them, contributing to their profit, and therefore their ability to grow even larger. Regulatory capture here is understood as a form of corruption and represents a "process through which special interests affect state intervention in any of its forms" [51]. Perceptions that agroholdings were able to influence political actors to allocate agricultural subsidies to themselves at the expense of smaller actors in the system were for example widespread, as is seen in this quote from a current/former public official: "The biggest corruption risks are in the subsidies. All the subsidy programs are I think $100 \%$ corrupted". Furthermore, perceptions that some form of payments or bribes were involved in the relationships between large companies and political actors were widespread. For example, a current/former member of an NGO stated that "in Ukraine, politics is business. Because it's not about like, investor with a business lobbying the government to do something. It's just business buying government or buying decisions they need". There were instances where this was also labeled by interviewees as political corruption, as demonstrated by this statement by a current/former academic when discussing that legislation had been changed regarding agricultural subsidies in favor of large businesses: "We know that big agricultural businesses, they lobbied, they had a lobby in the parliament, yes, and the parliament, everybody know that this is actually political corruption". The individual explained further that the loss of small producers due to this legislative change was billions of $\mathrm{UAH}$, but as agroholdings were now multi-billion dollar empires, they were able to influence members of parliament in every political party. 


\subsubsection{Summary of the Ukrainian Case}

In the current system, long-term fertility of the soils has the potential to be compromised when farmers resort to using sub-standard fertilizers and practice monoculture of cash crops that exhaust the soils in order to ensure maximum yield and profit. Small-scale farmers do this to survive financially in the sector, but their economic vulnerabilities might not present them with the option of practicing cultivation that supports long-term soil fertility. Even though there are no legal rules banning such practices, it compromises soil health and goes against best practices in soil quality management [52]. Most of the interviewees held perceptions of corruption risks, such as regulatory capture, as agroholdings were believed to have power over political actors. As ownership of the value chain is moving toward vertical integration in the sector, it ensures the economic efficiency of operations for agroholdings while at the same time causing the risk of small-scale farmers resorting to unsustainable management practices. The negative effect appears to be that soils are degrading in Ukraine as the incentives to care about nutrient levels in the soils are lacking, which has implications for the national economy as well as global food production.

The transition of the sector toward economies of scale, and the timing of that transition, originating in privatization, which was influenced by the neoliberal economics claim that private ownership would lead to a more effective and productive system, can be considered as the underlying relevant condition for this outcome.

\subsection{The Romanian Forestry Sector}

Forest ecosystems bring benefits such as biodiversity conservation, nutrient cycling, air and water purification, absorbing carbon from the atmosphere [53], and providing social and cultural benefits, although those benefits are often undervalued by decision makers [54]. Therefore, striking a balance between conserving forests and demands for exploiting the resource to support livelihoods is essential [55]. Forests cover approximately $30 \%$ of the territory of Romania [56,57] and have some of Europe's richest biodiversity [58]. They have traditionally served an important role for the Romanian economy, and still do, as forests provide employment for roughly 50 thousand persons [59] and revenues from timber exports represent $2.4 \%$ of total exports [60]. They are also considered to have a high social and environmental value for local population [61].

While Romania was never part of the Soviet Union, the country was a communist state where land and industry were nationalized and managed through a centralized economy after 1948. The fall of the communist regime in 1989 was followed by a shift toward a market-based economy, where a neoliberal vision opting for privatization schemes to best ensure market efficiency was embraced by policy makers [62]. Industry had to be privatized, and the process of forest land restitution began in 1991, giving it back to the pre-1948 owners [63,64], a process that is still in progress [56]. While around $66 \%$ of forest land was registered as publicly owned in 2012, exact figures on ownership structures are difficult to obtain since the restitution process is still ongoing [64].

The changes brought by the shift in ownership structures have added pressure to forest resources [65] and altered logging rates and patterns [66,67]. It has been described as a paradox that, even though the forestry sector was subjected to a rigorous legal framework in the post-communist era, Romania became known for illegal logging after 1990 [62].

\subsubsection{Forest Management}

Interviewees described how illegal harvesting of forest had been rampant in the years following the fall of the communist rule when forest land that had been confiscated by the state was beginning to be restituted back into the hands of private owners. According to the law, previous owners were entitled to 1 hectare of forest and obtained certificates for it, but it did not specify the exact geographical location. There were actors that saw an opportunity in that uncertainty and harvested forest that they were not entitled to. This was described by an interviewee from the harvesting sector: "And that moment, everybody went in the forest to cut, to clear cut 1 hectare of the forest. Because, getting money for 
1 hectare of the forest, it was your money, actually. It's your private business, your private property. And if I am not going in the forest to cut it, my neighbor will go there". A cadastre was established in 1996 [54], but forest land ownership categories were left undefined until the passing of the Forest Code in 2008 [68]. New forest owners appeared to be cutting their restituted forests to gain short-term profit, due to economic hardships, lack of knowledge on sustainable forest management, and uncertainty about the permanence of their newly obtained private property rights [66]. The high value for timber from old-growth forests may also have played a role [58].

The Romanian forest management system has been categorized as one with a low degree of freedom in decision making, as private forest owners have comparatively less rights for harvesting timber but more rights to exclude public access than in other European countries [69]. The country is divided into forest districts, which are all responsible for implementing forest management plans, produced by private or public companies on decennial bases [70]. The harvesting numbers generated for each unit are added up to account for the total allowable cut (TAC) each year. Forest owners are obliged to have a forest management plan for their forest, made every 10 years, if the forest property exceeds $10 \mathrm{ha}$, and have the option to contract management services from private forest management structures or the National Forest Administration, Romsilva [71].

\subsubsection{Consolidation in the Forestry Sector}

The narrative of the development of the sector, as presented by interviewees, was that the government invited foreign companies, which also go by the label 'multinational corporations', to come to the country and set up sawmills or wood processing facilities. Some of the multinationals also bought forest land, and as a result, some companies own the resource itself, as well as the processing facilities. They own storage facilities and export the commodities themselves, meaning they own a large part of the value chain. A current/former academic discussed how until the foreign companies appeared, wood processing was mainly done by small, local companies. The development has been toward company consolidation and vertical integration in the sector, driven by foreign investments, as actors are now fewer and larger. The remaining Romanian companies are "many, but small. So, they are facing difficulties in developing for many reasons. One of them being the development of those foreign investments." According to Vasile [72], the timber industry in Romania developed toward company consolidation during the post-socialist period, as middle-sized businesses grew larger while small ones disappeared. A large Austrian timber company that established a presence in the country in 2003 with a single wood processing plant had grown to five plants in 2020, highlighting that development [72].

The CLD in Figure 4 contains three reinforcing feedback loops, representing the dynamics that drive consolidation in the sector.

We begin with exploring Loop R1 through the variable of size of foreign companies in the forestry sector. We see that the large the size of the company, the more access it has to capital. As a current/former owner of a harvesting company explained: "Most of them [multinational corporations], they don't have a problem with cash. It flows, cash flows". The greater access to capital ultimately translates into the ability to buy up smaller, local companies, translating into foreign companies buying up smaller ones in the value chain, leading to increased consolidation of companies in the sector, resulting in a larger size of those foreign companies. Loop R2 then demonstrates that as the size of the foreign companies grows, so does their ability to maximize economic efficiencies and therefore their profit. As company profit grows, so does the ability to buy up smaller local companies, which ultimately comes back to increase the size of foreign companies in the sector at the expense of smaller local ones. In reinforcing Loop R3 at the bottom of Figure 3, we see that as the ability of foreign companies to maximize economic efficiency grows, so does profit and a greater ability to buy up smaller local companies. Those companies can be located at different stages and parts of the value chain, so ownership and control over the value chain grows through vertical integration in the sector, serving to increase the companies' 
ability to maximize economic efficiency. Therefore, foreign companies have the ability to benefit from the economies of scale by maximizing efficiency, which is the main driver behind the consolidation of companies in the sector. It has led to a growing capacity of the wood processing industry in Romania, which we discovered to be an important driver in the system, displayed at the top of Figure 3.

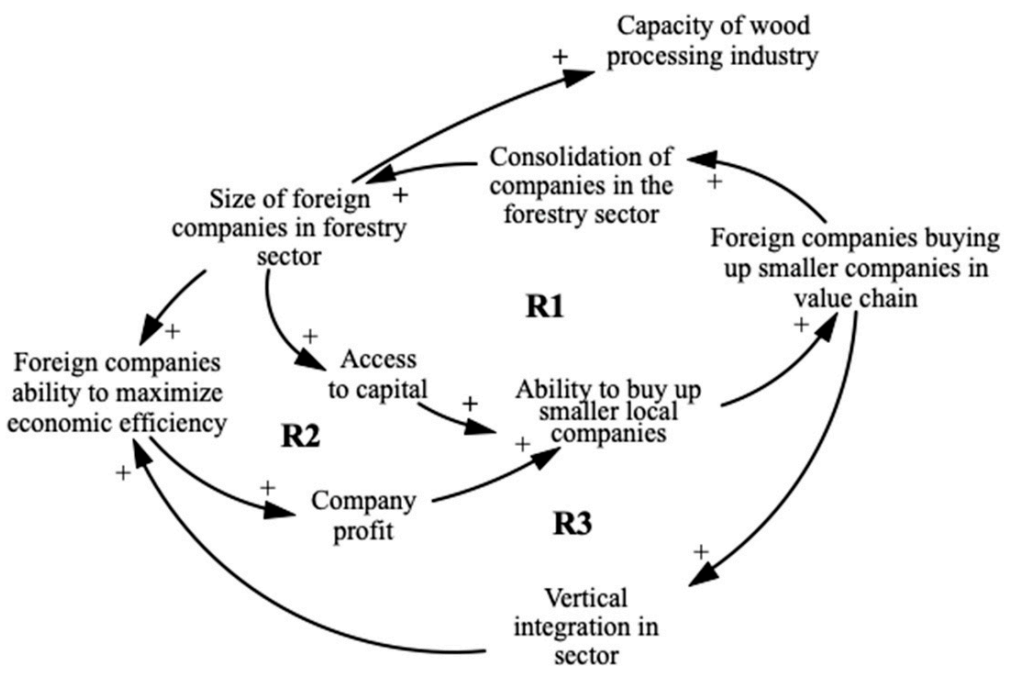

Figure 4. A CLD representing the dynamic behind consolidation of companies in the Romanian forestry sector.

Interviewees discussed a growing interest of the Romanian public in biodiversity conservation and stopping illegal logging, which has been fueled by media coverage of corrupt practices by foreign multinationals. There was widespread skepticism among the interviewees toward the corporations, as displayed by this comment from a current/former journalist: "Because they [multinational corporations] didn't come to invest, they came to make a profit. This is what businessmen do. He is not going to come here to help you, he is going to take money out of you". It has been suggested that media coverage of forest management in the country has drawn a negative image of the sector, painting it in starker colors than data on illegal logging allows for $[73,74]$. According to data from the Romanian National Forest Inventory (NFI) evaluation for 2013-2018, it is estimated that the volume of wood harvested annually from forests is approximately 38 million cubic meters [75]. There are those that claim the numbers are exaggerated [76], and NFI itself highlights that the numbers should be used with caution due to sampling errors [75]. Another report [56] states that during the last three decades, the total volume of harvested forest has increased and stands at 18 million cubic meters, and the reported volume of illegal logging between 2010 and 2017 ranges from 153 to 915 thousand cubic meters annually. However, the authors underline methodological challenges in estimating the volume of harvesting that is done illegally [56]. When it comes to the forest area, FAO suggests it has increased since 1990 from 6.4 million ha to 6.9 million ha in 2020 [57]. Interviewees expressed concerns over the reliability of these numbers, as well as availability of forest harvesting data, which contributes to uncertainty and skepticism surrounding it.

\subsubsection{Smaller Actors in the Forestry Sector}

In Figure 5, we have integrated the dynamics concerning illegal harvesting of forest and perceived corruption risks with Figure 4, and through that, we explore the question of what the main drivers are that generate corruption risks in the Romanian forestry sector. The consolidation and vertical integration in the forestry sector have left smaller, local actors vulnerable on many fronts. 


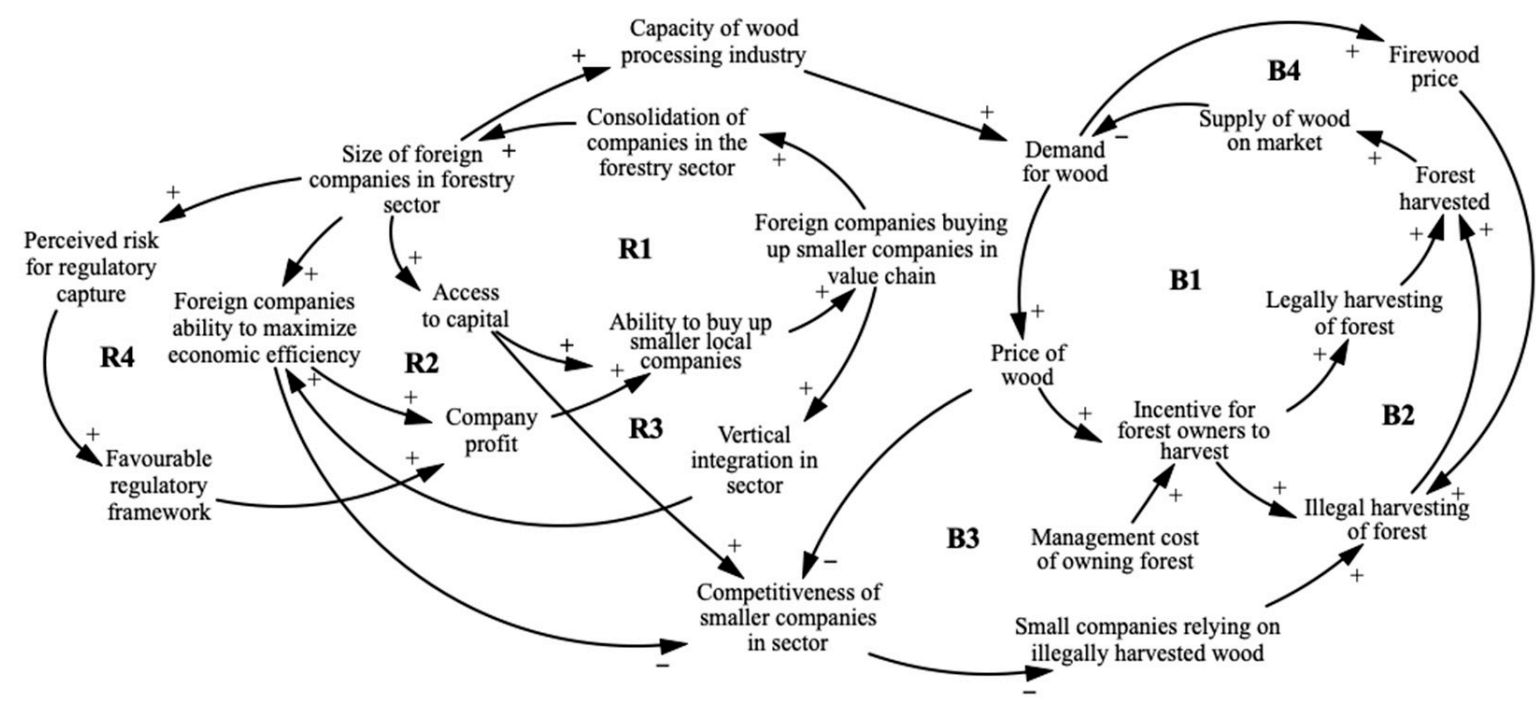

Figure 5. A CLD integrating the dynamics driving illegal harvesting of forest and perceived risk for corruption with Figure 4 .

We begin exploring balancing Loops B1 and B2 through the variable of demand for wood. Since a growth in demand coming from the wood processing industry results in a growing demand for wood, the price of wood increases with demand. As the price goes up, forest owners have added incentives to harvest trees in their forest. If their forest management plan allows for legal harvesting, that increases as the incentive goes up. Balancing Loop B2 does not take effect until the forest owners are willing to harvest more than what they are allowed, based on their forest management plan. The loop represents situations where forest owners are incentivized to harvest forest illegally if the demand exceeds the allowable cut. Both legal and illegal harvesting of forest increases the forest that is harvested, which adds supply of wood on the market, ultimately coming back to satisfy or meet demand for wood. However, it is not simply the price of wood that dictates harvesting decisions. With the new regulations regarding forest management introduced in 2008 , forest owners were obliged to pay for forest administration services, which includes having forest management plans set up and having a forest ranger guard the forest. A current/former forest owner association member described how some of them were paying more money for management services than they were receiving in revenue from owning and harvesting the forest. Those costs had to be paid annually, meaning forest owners could become vulnerable to engaging in schemes of underestimation, registering less standing volume in their forest management plans than there is in reality, to supplement their incomes by selling wood to the black market. As described by an individual with extensive experience in the sector, mainly from harvesting operations: "It's just telling that you have less, less wood on paper. Actually, you have, let's say 1 million cubic meters on paper. In reality you have 1.2 million in the forest. And those $20 \%$ are going on the black market as illegal wood. And everybody is happy". This is represented in the balancing Loop B3 in Figure 5. As demand for wood goes up, so does the price of wood. Higher wood prices mean that smaller companies are less competitive compared to large vertically integrated companies, as they are not able to pay as high prices and do not enjoy the same access to capital. Lower competitiveness means companies rely to a larger extent on illegally harvested wood in their business model, which increases illegal harvesting of forest. Harvesting companies in the sector are, for example, usually small in size, owned and operated by locals, and compete with one another. A former/current owner of a harvesting company discussed the issue of access to capital. The individual stated that since small harvesting companies were generally harvesting illegal wood to some extent, it was hard for them to go to the banks with business plans that covered only the legal side of the business. Therefore, the companies were trapped in a vicious cycle, relying on money from illegal logging to sustain their business and not having access to loans from banks to 
sustain the business because they could not prove it was profitable on paper. Moreover, since most companies operated this way, it was challenging to refrain from illegal logging. That would mean the company would no longer be competitive in the sector and go out of business. Since some harvesting companies were supplementing their businesses by selling illegal wood, others were forced to do so also in order to stay afloat. Increasing illegal harvesting of forest results in more forest being harvested, generating more supply of wood to satisfy demand.

Balancing Loop B4 at the top right of Figure 5 represents the role of firewood in these dynamics, even though interviewees did not all agree on the degree to which it contributes to illegal logging. As demand for wood grows, firewood prices increase. That is because large wood processing companies have increased their efficiency and can now obtain more value out of processing lower quality trees, which would previously have been sold as firewood. In fact, firewood prices in Romania increased by 150\% over the period from 2011 to 2017 and even more in the southern part of the country [77]. Approximately 3.75 million households in Romania rely on firewood as a main source of heating and $90 \%$ of those are located in rural areas [78]. It is therefore safe to assume that the rise of demand for wood, which has contributed to the increase in firewood prices, has caused added financial constraints on households in rural communities. As firewood prices increase, people increasingly rely on illegal harvesting to supply the material they need for household heating, which grows the supply of wood on the market, coming back to satisfy demand.

As companies in the sector have become larger, the capacity of the wood processing industry has led to a continuous growth in demand, which has become increasingly difficult to satisfy. As described by a current/former forest owner: "But they [small local wood processing companies] could not get, you know, truck-loads after truck-loads after truckloads of timber. For processing. That's I guess their [foreign companies in the sector] biggest problem, that what they caused was simply creating the capacity for this illegal timber cutting". Additionally, interviewees perceived that large companies accepted illegally harvested wood into their sawmills to meet their demand. This suggests that even though a development of increasing capacity and efficiency in the sector might appear favorable from an economic standpoint, the implications it had in this case were that it promoted illegal harvesting.

The last reinforcing Loop R4 on the left side of Figure 5 represents the common perception that large foreign companies in the sector had increasingly gained the ability to influence political leaders to their advantage, risking regulatory capture. Larger companies would then operate within a favorable legislative framework, ultimately enhancing their ability to increase their profit, further fueling consolidation in the sector and allowing large companies to grow larger. To give examples, a former/current journalist described that "when the legislation, the silvic, the forest legislation was changed, in the parliament, several deputies and senators said that they were receiving phone calls. Don't do that, don't do this. Don't vote that, don't change that." The reason they were asked not to change the legislation was in order to not upset the large multinational companies operating in the sector. The individual then gave examples of cases where public officials had ensured that the large multinationals would not be investigated regarding suspicion of engaging in illegal logging, concluding that "at some point, someone, you know, turned off the light. Several cases". There was also a widespread perception that political actors were benefitting from illegal logging, as political parties were being financed with money coming from illegal logging. Additionally, a current/former member of an NGO stated that "I don't know which direction it is, whether it's politics that influence the forestry or whether it's the forestry that influences the politics. But anyway, they go very well hand in hand. And it's a big mafia", a quote that serves to highlight the perceived connection between the forest industry and political actors. 


\subsubsection{Summary of the Romanian Case}

Forests are a valuable biophysical, social, and economic resource for Romania. However, the shift toward privatization in the forestry sector enacted after the fall of communism created two main dynamics, which have contributed to high rates of illegal deforestation in the country. On the one hand, large foreign companies entered the Romanian forestry sector, which led to consolidation of companies in the forestry sector, as smaller companies were bought up and vertically integrated in the supply chain. This process allowed large companies to maximize efficiency and generate a growing demand for wood, while pushing smaller, less efficient companies out of business. On the other hand, the surviving smaller businesses and actors had to deal with unequal competition from large companies, lack of access to credit, lack of regulatory support, and high management costs. The risk that they resort to illegally harvesting wood to survive financially increases, as it has enabled them to supplement their insufficient income generated through legal wood harvesting. This, together with the perceived risk of other actors engaging in corruption, acts to generate risks for unsustainable resource management.

If we revisit Ragin's simple resolution paradox in Table 1, we consider that the process of transition to economies of scale, initiated by privatization that was influenced by neoliberal economics, can be a relevant condition for explaining these outcomes.

\subsection{The Icelandic Fisheries Sector}

According to an assessment by FAO, the world marine fish stocks have continued to decline, and the "proportion of fish stocks that are within biologically sustainable levels decreased from $90 \%$ in 1974 to $66 \%$ in 2017" [79]. Scientists have claimed this development is the result of tragedy of the commons, as the resource is rarely governed as an individual private property, resulting in short-term planning [80].

Iceland has a long history as a fishing nation and catches $1 \%$ of the total marine capture production globally [79]. Fishing was based on rules of open access, and in the 1970s, Icelanders invested heavily in the sector [81]. However, the unlimited resource utilization meant conditions of important stocks, such as cod, worsened, and the Marine and Freshwater Research Institute (MFRI) published a so-called 'black report' in 1975 warning of the state of the cod stock, even predicting its collapse [81,82], sparking actions to limit catches. It became apparent in the early 1980s that those actions had not contributed to sustainable levels of the fish stocks [81] and that the system was economically wasteful [83]. As described by an interviewee with experience as a fisherman, the Icelandic fisheries were not sustainable at the time. "In the system as it was, it was tremendously difficult to catch fish. You needed to sail a long way. The cost of oil, for example, for fishing, was a huge part of the total cost. Because you needed to search for the fish". The aim of the fishing trip was also to catch as much fish as possible. Consensus was building around the premise that access to the resource needed to be restricted to prevent collapse of fishing stocks and a system based on a distribution of individual quotas was initiated for some species in 1984 [81]. Quotas were allocated to vessels based on the three previous years' catch history in that fishery $[83,84]$, known as grandfathering.

\subsubsection{The Icelandic ITQ System}

By the late 1980s, the debate on the fisheries management system was under growing influence of fisheries economics, with the discourse moving away from ecological protection toward that of economic efficiency [84]. Then, in 1990, a comprehensive law was passed in Iceland that introduced an Individual Transferable Quota (ITQ) system [81-83]. The main features of the ITQ system are that a percentage of the fish available for harvesting is divided into quota shares, held by private actors, and those shares are tradable. The goals of this system are to limit efforts to catch fish and fishery overcapitalization [85]. It is based on the notion that turning the catch quota into a market commodity and establishing private property rights for fish that have not been caught yet will ensure that fish stock harvesting levels harmonize with the long-term sustainability of the stock [86]. The Ice- 
landic transition to an ITQ system can therefore be described as a market-based approach to tackle the economic and ecological challenges facing the sector [87].

The Ministry of Fisheries and Agriculture sets an annual total allowable catch (TAC) in tons for how much can be harvested of each marine species, based on stock assessment recommendations from the Marine and Freshwater Research Institute [83]. Valid fishing licenses are needed for entry [81], and the quota shares for each species translate into a share of the TAC, which is calculated by multiplying the share percentage with the TAC, giving the size of the annual catch entitlement for each vessel [83]. Quotas can be separated from the vessel, and the vessel owner can transfer them to other vessel owners as an independent commodity [86]. There is, however, an upper limit to how large of a quota share can be owned by a private actor [88].

The benefits the system brought to Iceland were those of reduced average harvesting costs [81] and increased economic efficiency $[83,84]$. In general, the Icelandic ITQ system is viewed positively when evaluating the economic and biological successes of it [89]. Nevertheless, stakeholders have been reluctant to accept the system, and the political discontent of it relates to the initial allocation of quota, based on grandfathering [81]. The ones reaping the benefits of the current system are large quota owners, while fishermen and fishing communities did not do so to the same extent, and it has brought about substantial redistribution of wealth [86]. Due to the transferable nature of the quota between vessels, it was no longer tied to a community. Indeed, the quota was often sold off from rural coastal communities, which meant outmigration due to a decline in job opportunities and a subsequent decline in local commercial activity [90,91].

\subsubsection{Consolidation of Companies in the Fisheries Sector}

Open-access fishing can lead to a situation where too many boats go after too few fish, but since the goal of introducing ITQs in fisheries is to increase economic efficiency while ensuring sustainable stock levels, it is natural that the rules of the game lead to less but more efficient players through consolidation [91]. The consolidation of quota holdings in the Icelandic fisheries sector has occurred, but according to Agnarsson et al. [88], it has led to a decline both in the number of harvesting companies as well as vessels. Furthermore, from 2001 to 2014, the 25 largest companies in the sector increased their quota shares from $39 \%$ to $74 \%$ of the regular quotas [88]. However, even as there is a decline in absolute numbers of companies and vessels, those that remain continue to grow and accumulate more quota and processing capacity, resulting in a vertical integration in the value chain of large companies in the sector [90]. According to Palsson and Helgason, changes in the distribution of ITQs indicate growing inequalities between large and small-scale players in the fisheries sector [82]. We explore what drives the consolidation in the Icelandic fisheries sector in Figure 6.

Profit plays a central role and in reinforcing loop R1, an increase in profit means companies have more ability to buy up smaller companies in the sector. That translates into smaller companies being bought up in the sector, which are not limited to only those that have vessels out at sea. The companies could, for example, own land-based processing plants or be export-oriented fish product businesses. This translates into further consolidation of companies in the sector, as well as contributing to the vertical integration in the sector, as demonstrated by reinforcing Loop R2. Increased consolidation means that the size of companies in the fisheries sector becomes larger. That as well as further integration translates into an improvement in the ability of companies to maximize their economic efficiency, ultimately leading to increased profits. Access to capital was identified as an important variable, represented in Loop R3, which harmonizes with Palsson and Helgason [82], but access to capital from the Icelandic banking system played a vital role for larger players to accumulate ITQ shares. As access to capital grows, companies have increased their ability to buy more quota, and as more quota is bought, the size of the companies' share of ITQs grows. A bigger size of ITQ shares means companies have more access to capital since banks consider the companies to be more valuable. 
In reinforcing Loop R4, we demonstrate that as attaining quota shares goes up with more profit, companies have increased their chance of having quota for diverse species, translating into having a quota for fish species they catch to a larger degree, which increases the ability to maximize economic efficiency, coming back to increase profit.

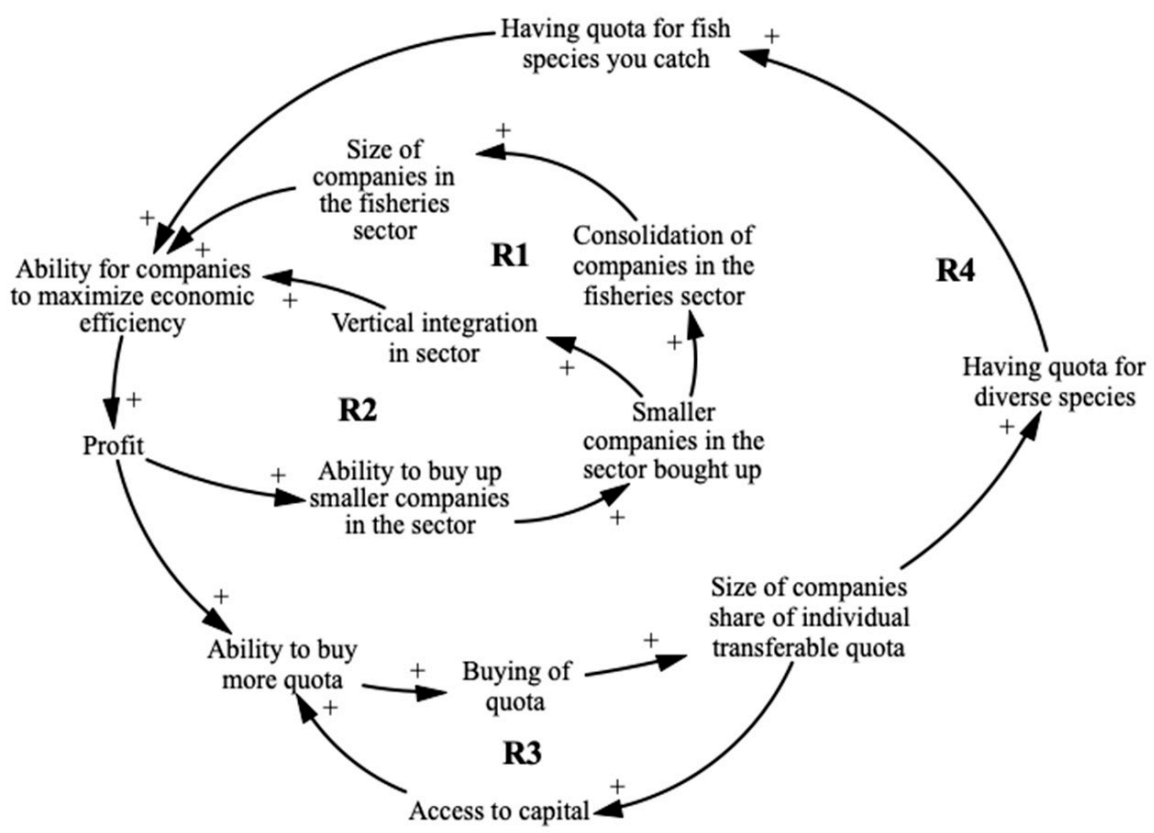

Figure 6. A CLD representing the dynamic behind consolidation of companies in the Icelandic fisheries sector.

In Figure 7, we have introduced an additional structure to the CLD in Figure 6, where we explore the dynamics driving the perceived risk of corruption in the system and the vulnerabilities of smaller actors.

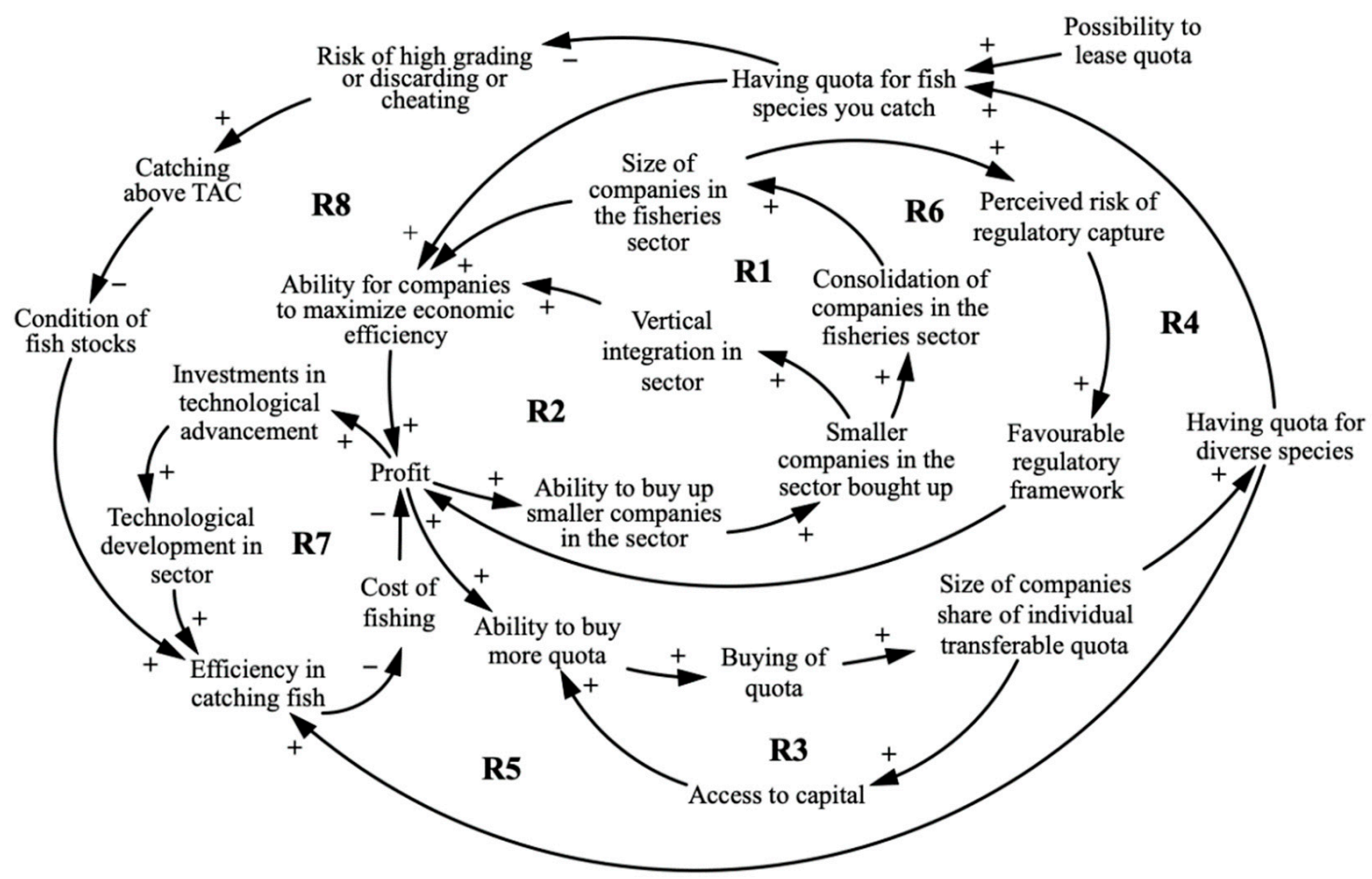

Figure 7. A CLD that integrates Figure 6 with dynamics that drive perceived corruption risks and the vulnerabilities of smaller actors in the fisheries management system. 
Loop R7 on the left side demonstrates how an increase in profit translates into more investments in technological advancements, which lead to more technological development in the sector. This enhances the efficiency in catching fish, reducing the cost involved and increasing profit. Interviewees generally discussed the technological advancements in the sector positively as they had brought the Icelandic fishing industry to the forefront of technological advancement on a global level. We proceed to reinforcing Loop R5 on the bottom of Figure 7 and begin with the variable of efficiency in catching fish. As it goes up, the cost of fishing goes down, serving to increase the profit involved in the operation. It means companies can buy more quota and increase their share size in the ITQ, further enabling them to have a quota for diverse species. That ultimately serves to enhance the efficiency of catching fish, as one cannot control which species end up in the fishing net.

Reinforcing Loop R8 demonstrates that the transferability of quota shares is meant to decrease the risk of high-grading, discarding, and other forms of cheating by ensuring flexibility as the quota can be transferred between vessels, depending on how much of each species are caught in the fishing net. When a company has a large individual transferable quota, it has a quota for more diverse species, increasing the probability of having a quota for the fish species it catches, resulting in less probability of discarding by-catch, highgrading, and bypassing the catch to be weighed on the harbor. When dead fish smaller in size in the catch are thrown back into the sea to have only larger and more valuable ones that count toward the quota, that is labeled as high-grading. Reduction in high-grading and discarding of by-catch serves to improve conditions of the fish stocks. Improved stock conditions lead to more economic efficiency in catching fish, more profit, and ultimately an increase in the size of the company share of ITQ. Therefore, if one vessel catches fish it does not have a quota for, the company that owns the vessel can opt for transferring quota shares to that vessel if they have an unused quota on other vessels, benefitting from economies of scale. The other option would be for the vessel to lease some of the quota from other companies, if they have run out of the quota shares entitled to them for that species. The system as described here contains no balancing loops.

The aforementioned loops can act as virtuous reinforcing cycles for those companies that have, for one reason or another, a competitive edge and are able to maximize their economic efficiency. However, for those companies that have been disadvantaged by the current fisheries management system, they can act as vicious reinforcing cycles. If a player in the system does not have quota for diverse species, they will not have a quota for the fish species they catch to the same extent as players who do. Their ability to maximize economic efficiency decreases as a result, with less profit and decreased ability to buy quota, negatively impacting their ability to increase the size of their ITQ share and having a quota for the species they catch. Not having a quota for caught fish species could therefore increase the risk of cheating, such as high-grading and discarding of by-catch. As described by a current/former fisherman: "There is nothing comical about being out at sea and needing to discard the entire catch, you know. There are only two options in a situation like that. Either discard the catch or bypass it away from being weighed at the harbor. And that is exactly what is happening. And at a big scale". The individual further described how the flexibility to transfer quota in the system was the main positive feature of it, but only if you had enough quota in a diverse set of species. Those positive features were mainly enjoyed by larger companies, but smaller players that perhaps only held quota in one species were left with one legal option: to lease quota for the catch. The leasing price could be higher than what was economically feasible for them, increasing the risk of opting for cheating to survive financially. The dilemma was already identified by Eythorsson in 1996, suggesting that when the lease price for cod rose steeply in 1994 and 1995, reports of cod discarding increased [86]. The lease price increased by a factor of 2-3 from 1992 to 2008, but it can rise when demand exceeds the supply of quota [81].

Lastly, reinforcing Loop R6 represents how considering their growing size, interviewees had widespread perceptions that companies in the fishing sector had an increasing ability to lobby for their interests and influence the regulatory framework. We label this 
as a perceived risk of regulatory capture, ultimately serving to increase their profits and allow them to grow larger. There was a common perception among interviewees that quota owners were powerful actors that not only had influence in their local communities but also on decision making in the sector. To provide a few examples, a current/former academic claimed that the solidarity between large quota owners and their power to resist changes to the system should not be underestimated, and that they "own a big part of the political parties. They pay high amounts of money to political party funds. Apparently, they have their own MPs. To look after their interests in the parliament and elsewhere. There is a great deal of corruption there as well". Additionally, as described by a current/former public official: "And then we have the association of quota owners. Throughout the years they have gotten away with controlling of legislation and regulations and, there has been no change thereof". A current/former member of parliament stated that for a long time, people did not consider corruption to exist in Iceland, but that, in recent years, it has increasingly been accepted that it does.

\subsubsection{Summary of the Icelandic Case}

Throughout the years, there has been a decline in the TAC to secure sustainable levels of the fish stocks. Smaller companies are not as economically resilient to deal with a decline in the TAC and are not as economically competitive as the larger companies that have increased vertical integration of operations through consolidation since access to the resource was de facto privatized. Smaller actors in the resource management system can resort to unsustainable and illegal management practices such as discarding by-catch to survive in the sector financially. Most interviewees perceived that the current system offered processes where larger actors were able to gain advantages through political influence over decision makers, defined here as regulatory capture. Quota owners that own the large vertically integrated companies were identified as a powerful group, but as McCay has pointed out, the power in ITQ systems will be held by the ITQ owners [85]. The main dynamics contributing to risks of unsustainable fisheries management practices and perceived corruption risks were identified to stem from the inequalities between large and small actors in the sector. We consider the transition to economies of scale to be the underlying condition that can explain the outcome. That process was initiated when access to the resource was de facto privatized, which was influenced by neoliberal economic thinking.

\section{Discussion}

Our analysis is based on Ragin's simple paradox resolution where cases A, B, and $\mathrm{C}$ are different, yet they experience similar outcomes [21]. The task is then to explore and describe what causally relevant similarities between the cases might explain a similar outcome. As previously discussed in Table 1, the main differences between the cases relate to the population size and density, degree of European integration, economic development, ranking on the $\mathrm{CPI}$, and resource sectors under study. The similar outcomes of the three cases were privatization of natural resources, consolidation of companies in those sectors, perceived corruption risks, and the perceived risk of unsustainable management practices. From the analysis of each individual case, we have observed common dynamics that can be characterized as a transition to economies of scale, as captured in Figure 8. What we also found was that this transition was taking place around the same time in all cases and was facilitated by changing political and economic ideology.

Here, we see reinforcing Loops R1 and R2, demonstrating the common dynamics that have allowed larger companies increased access to capital, which can be used to buy up smaller companies, resulting in increased consolidation of companies and the increasing size of companies in the sector. As smaller companies are bought up, larger companies seek vertical integration, since gaining ownership of larger parts of the value chain allows for enhanced economic efficiency, which increases profit, allowing for further ability to buy up smaller companies in the sector. Company consolidation and vertical integration of larger 
players in the sectors bring economic efficiency of operations. However, a more restricted access of capital for smaller players serves to disadvantage them since it reduces their competitiveness. Smaller actors and companies can lack support, as well as competitive edge, and are left with limited options to survive in a market dominated by large and powerful actors. That increases the risk that they resort to unsustainable and sometimes illegal resource exploitation practices, such as discarding by-catch instead of leasing their quota for it, applying sub-standard fertilizers on soils to maximize yields every harvest, or harvesting forest illegally to be sold to processing plants to satisfy a growing demand. We also found that in all cases, large actors and companies were generally perceived to gain unfair advantages in light of their size and power over decision makers, as perceptions of corruption risks, such as regulatory capture, were widespread.

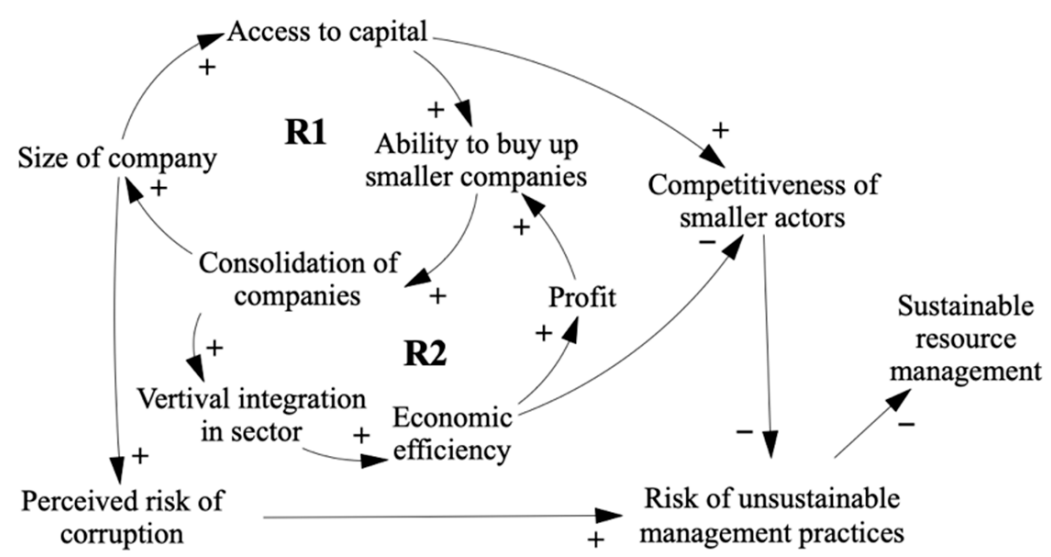

Figure 8. A CLD representing the main dynamics driving the risk of unsustainable management practices in all cases and the role of perceived corruption.

As Robbins [13] suggested, corruption can be viewed as alternative norms rather than deviation from rules. Perceptions that large companies in some way or form have unfair advantages in these resource sectors due to their financial and political power contributes to a higher risk of unsustainable management practices. Because when the management systems are perceived as unfair by smaller actors in the system, such practices have the potential to become alternative norms. If corruption is viewed as a collective action problem in this context, smaller actors could be incentivized to engage in corruption, if that is what they have come to expect of other actors.

The transition to economies of scale is a process initiated by decisions to alter ownership structures in the resource sectors under question. We argue that the underlying similarities between the different cases that can explain the similar outcomes also originates in the timing of the privatization of the resources. Although for different reasons, privatization was adopted in all three cases around the same time in early 1990s, with the prevalent neoliberal promise of more sustainable resource management that will bring socioeconomic prosperity. In Iceland, the access to the resource was privatized, which facilitated the transition to economies of scale in the industry, while both the industry as well as the resource was privatized in Romania and Ukraine. It was the worsening condition of the Icelandic fish stocks that prompted action that ultimately steered the fisheries management system toward one where access to the resource was privatized, while it was the fall of the communist regime and ideology in Romania and Ukraine that resulted in the privatization of both arable land and forest land, as well as the industries. The transition from a nationalized ownership to private ownership was caused by different factors in each case, but the underlying assumption of the dominant neoliberal economic ideology at the time was that private ownership meant better management, since people take better care of what they own privately than a property shared by a group. Even though the reasons for why privatization occurred in the three cases are different, the prevailing neoliberal discourse at the time means that we can observe similar dynamics in their transition and 
the similar outcome. We suggest that the relevant question is not why privatization took place, but rather how it took place. The neoliberal direction turned the natural resource management systems in all cases to those favoring pursuit of profit through enhanced economic efficiency, and therefore transitioning to economies of scale.

As larger companies can invest in technology that increases economic efficiency and replaces the need for a large workforce, this has resulted in a decrease in employment opportunities in rural areas and subsequent emigration. This can be seen in the results of the present study: large fishing companies in Iceland increased at the expense of small fishing companies, a process that contributed to the decline of many small fishing-dependent coastal communities. Large multinational companies with a robust vertical integration in the value chain and considerable access to capital took over smaller Romanian forest holdings, gradually consolidating their market position. This happened at the expense of smaller scale businesses positioned somewhere along the value chain in the forestry sector and upon which many rural communities depended. In Ukraine, small-scale farmers have been pushed out of business by large agroholdings, which have come to dominate in the sector. That has the potential to negatively impact communities dependent on those resources and make them more receptive to accepting unsustainable practices as standards.

\section{Conclusions}

Renewable resources are vital for food production, biodiversity conservation, climate change mitigation, and socioeconomic wellbeing, underpinning the importance of their sustainable management. This study investigated the management of arable land soils in Ukraine, forests in Romania, and fisheries in Iceland in an effort to gain an understanding of assumptions and perceptions of motivations that shape individual actions within the sectors, as well as their implications. The aim was to uncover the main drivers and dynamics contributing to unsustainable management practices and the role corruption plays in that context. The results indicate that the dynamics driving the transition to economies of scale in all cases and its links to processes of resource privatization that followed the neoliberal guidelines prevalent in the 1990s are possible relevant similarities as defined by this research. The processes, although different, since both the resources themselves as well as the industries surrounding them were privatized in Ukraine and Romania, while access to the resource was de facto privatized in Iceland, led in all cases to a consolidation of large vertically integrated companies and their dominance in the sectors. Meanwhile, smaller actors in the sectors can be left with resorting to adopt unsustainable resource management practices, such as applying sub-standard nutrients to soils, illegal logging, and discarding by-catch, to survive in a competitive market environment, sometimes with increasing operational costs and limited access to finance. The resulting inequalities between large and small actors in the renewable resource management systems serves as a main driver of perceived corruption risks in the sectors, such as regulatory capture. Higher economic efficiency in the sectors is therefore not a guarantee of sustainable resource management in itself. Even though there are limitations to this research, it highlights that further research directed toward elucidating knowledge of the privatization processes that took place in each case has relevance for understanding policies aimed at tackling corruption risks in resource management systems. It also underlines the growing importance of understanding the complex relationships between the economy, society, and natural resources and the role corruption plays in that context to better realize what is needed for implementing Agenda 2030 on sustainability.

Author Contributions: Conceptualization, J.G.; methodology, J.G., S.S., K.V.R. and I.S.; analysis, J.G., S.S., K.V.R. and I.S.; investigation, J.G.; data curation, J.G.; writing —original draft preparation, J.G.; writing—review and editing, J.G., S.S., K.V.R. and I.S.; supervision, S.S., K.V.R. and I.S.; project administration, S.S., K.V.R. and I.S.; funding acquisition, K.V.R. and I.S. All authors have read and agreed to the published version of the manuscript. 
Funding: This project has received funding from the European Union's Horizon 2020 research and innovation programme under the Marie Sklodowska-Curie grant agreement No 675153.

Institutional Review Board Statement: The study was conducted according to the guidelines of the Declaration of Helsinki, and a reference obtained from the Research Ethics Committee of University of Iceland (protocol code 17-026, 23 November 2017).

Informed Consent Statement: Informed consent was obtained from all subjects involved in the study.

Data Availability Statement: The data are not publicly available to ensure promised anonymity of interviewees.

Acknowledgments: The authors would like to extend gratitude to all the interviewees that made this research possible.

Conflicts of Interest: The authors declare no conflict of interest. The funders had no role in the design of the study; in the collection, analyses, or interpretation of data; in the writing of the manuscript; or in the decision to publish the results.

\section{References}

1. Svedrup, H.; Ragnarsdottir, K.V. Natural Resources in a Planetary Perspective. Geochem. Perspect. 2014, 3, 129-130. [CrossRef]

2. Meadows, D.H.; Meadows, D.L.; Randers, J.; Behrens, W. The Limits to Growth: A Report for the Club of Rome's Project on the Predicament of Mankind; Potomac Associates Book; Earth Island Limited: London, UK, 1972; ISBN 9780856440106.

3. Hardin, G. The Tragedy of the Commons. Science 1968, 162, 1243-1248. [CrossRef] [PubMed]

4. Ostrom, E. Governing the Commons: The Evolution of Institutions for Collective Action; Cambridge University Press: Cambridge, UK, 1990.

5. May, P.J. Social Regulation. In The Tools of Government: A Guide to the New Governance; Salamon, L.M., Ed.; Oxford University Press: Oxford, UK, 2002; pp. 156-185.

6. Palahí, M.; Pantsar, M.; Costanza, R.; Kubiszewski, I.; Potočnik, J.; Stuchtey, M.; Nasi, R.; Lovins, H.; Giovannini, E.; Fioramonti, L.; et al. Investing in Nature as the True Engine of Our Economy: A 10-Point Action Plan for a Circular Bioeconomy of Wellbeing; European Forest Institute: Sarjanr, Finland, 2020; ISBN 978-952-5980-92-9.

7. FAO. FAO 50th Anniversary Declaration on Food and Agriculture "The Quebec Declaration"; FAO: Rome, Italy, 1995.

8. FAO. Progress on the Sustainable Development Goals/2030 Agenda for Sustainable Development Executive. In Proceedings of the Forty-first Session, Rome, Italy, 22-29 June 2019.

9. FAO. SAFA Guidelines: Sustainability Assessment of Food and Agriculture Systems; FAO: Rome, Italy, 2014; ISBN 978-92-5-108485-4.

10. Williams, A.; Le Billon, P. Introduction. In Corruption, Natural Resources and Development: From Resource Curse to Political Ecology; Williams, A., Le Billon, P., Eds.; Edward Elgar Publishing: Cheltenham, UK, 2017; pp. 1-14, ISBN 9781785361197.

11. Kolstad, I.; Søreide, T.; Williams, A. Corruption in Natural Resource Management: An Introduction. U4 Brief 2008, 2. Available online: https://www.u4.no/publications / corruption-in-natural-resource-management-an-introduction.pdf (accessed on 25 April 2021). [CrossRef]

12. Transparency International. Corruption Perceptions Index; Transparency International: Berlin, Germany, 2010.

13. Robbins, P. The Rotten Institution: Corruption in Natural Resource Management. Political Geogr. 2000, 19, 423-443. [CrossRef]

14. Sumaila, U.R.; Jacquet, J.; Witter, A. When bad gets worse: Corruption and fisheries. In Corruption, Natural Resources and Development: From Resource Curse to Political Ecology; Williams, A., Le Billon, P., Eds.; Edward Elgar Publishing: Cheltenham, UK, 2017; ISBN 9781785361197.

15. Persson, A.; Rothstein, B.; Teorell, J. Getting the basic nature of systemic corruption right: A reply to Marquette and Peiffer. Governance 2018, 32, 799-810. [CrossRef]

16. Mungiu-Pippidi, A. Controlling Corruption Throught Collective Action. J. Democr. 2013, 24, 102-115. [CrossRef]

17. Lambsdorff, J.G. The Institutional Economics of Corruption and Reform: Theory, Evidence and Policy; Cambridge University Press: Cambridge, UK, 2007; ISBN 9780511274183.

18. Rose-Ackerman, S. Corruption: A Study in Political Economy; Academic Press: New York, NY, USA, $1978 ;$ ISBN 9781483289069.

19. Gailmard, S. Accountability and principal-agent theory. In The Oxford Handbook of Public Accountability; Bovens, M., Goodin, R.E., Schillemans, T., Eds.; Oxford University Press: Oxford, UK, 2014.

20. Jain, A.K. Corruption: A review. J. Econ. Surv. 2001, 15, 71-121. [CrossRef]

21. Ragin, C.C. The Comparative Method: Moving Beyond Qualitative and Quantitative Strategies; University of California Press: Berkeley, CA, USA, 1987.

22. Arksey, H.; Knight, P. Interviewing for Social Scientists; Sage Publications: London, UK, 1999.

23. Stake, R.E. The Art of Case Study Research; Sage Publications: Thousand Oaks, CA, USA, 1995.

24. The World Bank Population Density (People per sq. km of Land Area). Available online: https://data.worldbank.org/indicator/ EN.POP.DNST (accessed on 13 June 2021). 
25. The World Bank Population, Total. Available online: https://data.worldbank.org/indicator/SP.POP.TOTL (accessed on 13 June 2021).

26. Transparency International Corruption Perceptions Index. Available online: https://www.transparency.org/cpi2019?/news/ feature/cpi-2019 (accessed on 16 February 2020).

27. The World Bank GNI per Capita, Atlas Method (Current US\$). Available online: https://data.worldbank.org/indicator/NY.GNP. PCAP.CD (accessed on 13 June 2021).

28. Reed, M.S.; Graves, A.; Dandy, N.; Posthumus, H.; Hubacek, K.; Morris, J.; Prell, C.; Quinn, C.H.; Stringer, L.C. Who's in and why? A typology of stakeholder analysis methods for natural resource management. J. Environ. Manag. 2009, 90, 1933-1949. [CrossRef]

29. Durham, E.; Baker, H.; Smith, M.; Moore, E.; Morgan, V. The BiodivERsA Stakeholder Engagement Handbook; BiodivERsA: Paris, France, 2014.

30. Gunnarsdóttir, I.; Davíðsdóttir, B.; Worrell, E.; Sigurgeirsdottir, S. It is best to ask: Designing a stakeholder-centric approach to selecting sustainable energy development indicators. Energy Res. Soc. Sci. 2021, 74. [CrossRef]

31. Robson, C. Real World Research: A Resource for Social Scientists and Practitioner-Researchers; Blackwell Publishers: Oxford, UK, 1993.

32. Roulston, K. Analysing interviews. In The Sage Handbook of Qualitative Data Analysis; Metzler, K., Ed.; Sage Publications: London, UK, 2014; pp. 297-312, ISBN 978-1-4462-0898-4.

33. Meadows, D.H. Thinking in Systems: A Primer; Wright, D., Ed.; Chelsea Green Publishing: Hartford, VT, USA, 2008.

34. Reichel, A. (Re-)Structuration of System Dynamics. In Proceedings of the 22nd International Conference of the System Dynamics Society, Oxford, UK, 25-29 July 2004.

35. Sterman, J. Business Dynamics: Systems Thinking and Modeling for a Complex World; McGraw-Hill Higher Education; Irwin/McGrawHill: New York, NY, USA, 2000; ISBN 9780072311358.

36. Doyle, J.K.; Ford, D.N. Mental models concepts for system dynamics research. Syst. Dyn. Rev. 1998, 14, 3-29. [CrossRef]

37. Lane, D.C. Rerum cognoscere causas: Part II-Opportunities generated by the agency/structure debate and suggestions of system dynamics. Syst. Dyn. Rev. 2001, 17, 293-309. [CrossRef]

38. Turner, B.L.; Kim, H.; Andersen, D.F. Improving coding procedures for purposive text data: Researchable questions for qualitative system dynamics modeling. Syst. Dyn. Rev. 2013, 29, 253-263. [CrossRef]

39. Spicer, J. Representation and Dynamic Implications of Mental Models of Food Systems. In Proceedings of the 33rd International Conference of the System Dynamics Society, Cambridge, MA, USA, 19-23 July 2015.

40. Kim, H.; Andersen, D.F. Building confidence in causal maps generated from purposive text data: Mapping transcripts of the Federal Reserve. Syst. Dyn. Rev. 2012, 28, 311-328. [CrossRef]

41. Charmaz, K. Constructing Grounded Theory: A Practical Guide through Qualitative Analysis; Sage Publications: London, UK, 2006; ISBN 9780761973522.

42. Fileccia, T.; Guadagni, M.; Hovhera, V.; Bernoux, M. Ukraine-Soil Fertility to Strengthen Climate Resilience: Preliminary Assessment of the Potential Benefits of Conservation Agriculture: Main Report (English); FAO: Rome, Italy, 2014; Volume 1, p. 31.

43. Mamonova, N. Resistance or adaptation? Ukrainian peasants' responses to large-scale land acquisitions. J. Peasant Stud. 2015, 42, 607-634. [CrossRef]

44. Stupak, N. Impact of Agricultural Transition on Soil Protection in Ukraine: The Role of Institutional Change. Land Use Policy 2016, 55, 86-97. [CrossRef]

45. fao.org FAO Kicks off Project Aimed at Tackling Land Degradation in Ukraine. Available online: http://www.fao.org/europe/ news / detail-news/en/c/1128337/ (accessed on 26 June 2021).

46. Lerman, Z. Land Reform and Farm Restructuring in Ukraine. Probl. Post-Communism 1999, 46, 42-55. [CrossRef]

47. Keyzer, M.A.; Merbis, M.D.; Witt, R.; Heyets, V.; Borodina, O.; Prokopa, I. Farming and rural development in Ukraine. JRC Sci. Policy Rep. 2012.

48. International Trade Administration Ukraine Adopts Land Reform. Available online: https://www.trade.gov/market-intelligence/ ukraine-adopts-land-reform (accessed on 21 November 2020).

49. Visser, O.; Spoor, M. Land grabbing in post-Soviet Eurasia: The world's largest agricultural land reserves at stake. J. Peasant Stud. 2011, 38, 299-323. [CrossRef]

50. Shikula, M.K. A mechanism for the self-regulation of fertility in Ukrainian chernozems. In Soil Quality, Sustainable Agriculture and Environmental Security in Central and Eastern Europe; Wilson, M.J., Maliszewska-Kordybach, B., Eds.; Springer Science \& Business Media: Berlin/Heidelberg, Germany, 2012; pp. 259-266, ISBN 9401141819.

51. Dal Bó, E. Regulatory capture: A review. Oxford Rev. Econ. Policy 2006, 22, 203-225. [CrossRef]

52. FAO. Voluntary Guidelines for Sustainable Soil Management; FAO: Rome, Italy, 2017.

53. Siry, J.P.; Cubbage, F.W.; Rukunuddin, M. Sustainable forest management: Global trends and opportunities. For. Policy Econ. 2005, 7, 551-561. [CrossRef]

54. United Nations. Environmental Performance Reviews: Romania; United Nations: New York, NY, USA; Geneva, Switzerland, 2012.

55. FAO; UNEP. The State of the World's Forests 2020. Forests, Biodiversity and People; FAO: Rome, Italy, 2020.

56. Ciceu, A.; Radu, R.; García-Duro, J. National Forestry Accounting Plan of Romania for the First Compliance Period (2021-2025); Institutului Național de Cercetare-Dezvoltare în Silvicultură „Marin Drăcea” (INCDS): Voluntari, Romania, 2019.

57. FAO. Global Forest Resource Assessment 2020 Report: Romania; FAO: Rome, Italy, 2020. 
58. Anfodillo, T.; Carrer, M.; Dalla Valle, E.; Giacoma, E.; Lamedica, S.; Pettenella, D. Activity 2.7: Forestry and Timber Industry Report on Current State of Forest Resources in the Carpathians; INTERREG III B CADSES Programme Carpathian Project Universita Degli Studi Di Padova: Padova, Italy, 2008.

59. Eurostat Forests, Forestry and Logging. Available online: https://ec.europa.eu/eurostat/statistics-explained/index.php/Forests, _forestry_and_logging\#Forests_and_other_wooded_land\%0Ahttps://ec.europa.eu/eurostat/statistics-explained/pdfscache/ 52476.pdf (accessed on 10 March 2021).

60. Romania Insider More than Half of Romania's Wood Exports Go Outside EU. Which Are the Biggest Markets? Available online: https: / / www.romania-insider.com/more-half-romanias-wood-exports-go-outside-eu-which-are-biggest-markets (accessed on 15 March 2021).

61. UNEP. Carpathians Environment Outlook; UNEP: Geneva, Switzerland, 2007.

62. Drăgoi, M.; Toza, V. Did Forestland Restitution Facilitate Institutional Amnesia? Some Evidence from Romanian Forest Policy. Land 2019, 8, 99. [CrossRef]

63. Abrudan, I.V. A decade of non-state administration of forests in Romania: Achievements and challenges. Int. For. Rev. 2012, 14, 275-284. [CrossRef]

64. Nichiforel, L.; Bouriaud, L.; Nonić, D.; Dorondel, S.; Măntescu, L.; Terpe, H. Forest Land Ownership Change in Romania; COST Action FP1201 FACESMAP Country Report; European Forest Institute Central-East and South-East European Regional Office: Vienna, Austria, 2015.

65. Ioras, F.; Abrudan, I.V. The Romanian forestry sector: Privatisation facts. Int. For. Rev. 2006, 8, 361-367. [CrossRef]

66. Knorn, J.; Kuemmerle, T.; Radeloff, V.C.; Szabo, A.; Mindrescu, M.; Keeton, W.S.; Abrudan, I.; Griffiths, P.; Gancz, V.; Hostert, P. Forest restitution and protected area effectiveness in post-socialist Romania. Biol. Conserv. 2012, 146, 204-212. [CrossRef]

67. Knorn, J.; Kummerle, T.; Radeloff, V.C.; Keeton, W.S.; Gancz, V.; Biris, I.-A.; Svoboda, M.; Griffiths, P.; Hagatis, A.; Hostert, P. Continued loss of temperate old-growth forests in the Romanian Carpathians despite an increasing protected area network. Environ. Conserv. 2012, 40, 182-193. [CrossRef]

68. Marinchescu, M.; Halalisan, A.F.; Popa, B.; Abrudan, I.V. Forest administration in Romania: Frequent problems and expectations. Not. Bot. Horti Agrobot. Cluj-Napoca 2014, 42, 588-595. [CrossRef]

69. Nichiforel, L.; Keary, K.; Deuffic, P.; Weiss, G.; Thorsen, B.J.; Winkel, G.; Avdibegović, M.; Dobšinská, Z.; Feliciano, D.; Gatto, P.; et al. How private are Europe's private forests? A comparative property rights analysis. Land Use Policy 2018, 76, 535-552. [CrossRef]

70. Halalisan, A.F.; Abrudan, I.V.; Popa, B. Forest management certification in Romania: Motivations and perceptions. Forests 2018, 9 , 425. [CrossRef]

71. Schmithüsen, F.; Hirsch, F. Geneva Timber and Forest Study Paper 26; United Nations: Geneva, Switzerland, 2010.

72. Vasile, M. The other frontier: Forest rush and small-scale timbermen of postsocialist Transylvania. J. Peasant Stud. 2020, 1-26. [CrossRef]

73. Palaghianu, C.; Nichiforel, L. Between perceptions and precepts in the dialogue on Romanian forests. Bucov. For. 2016, 16, 3-8. [CrossRef]

74. Palaghianu, C.; Dutca, I. Afforestation and reforestation in Romania: History, current practice and future perspectives. Reforesta 2017, 54-68. [CrossRef]

75. IFN National Forest Inventory: Forest Resource Assessment in Romania. Available online: http://roifn.ro/site/rezultate-ifn-2/ (accessed on 21 November 2020).

76. Romania Insider Romanian Forest Owners Claim Illegal logging Exaggerated by Media. Available online: https://www.romaniainsider.com/ro-forest-owners-illegal-logging-exagerrated (accessed on 15 March 2021).

77. Ziarul Financiar Cătălin Tobescu, Director Fordaq: “Prețul Lemnului de foc a Luat-o Razna. S-a Ajuns la un Preţ de 500-600 lei Metrul Cub în Sudul Ţării". Available online: https://www.zf.ro/constructii-imobiliare/catalin-tobescu-director-fordaqpretul-lemnului-de-foc-a-luat-o-razna-s-a-ajuns-la-un-pret-de-500-600-lei-metrul-cub-in-sudul-tarii-16844097 (accessed on 15 March 2021).

78. Neacsa, A.; Panait, M.; Muresan, J.D.; Voica, M.C. Energy poverty in european union: Assessment difficulties, effects on the quality of life, mitigation measures. Some evidences from Romania. Sustainability 2020, 12, 4036. [CrossRef]

79. FAO. The State of World Fisheries and Aquaculture 2020: Sustainability in Action; FAO: Rome, Italy, 2020; ISBN 9789251326923.

80. Grainger, C.A.; Parker, D.P. The political economy of fishery reform. Annu. Rev. Resour. Econ. 2013, 5, 369-386. [CrossRef]

81. Matthiasson, T.; Agnarsson, S. Property Rights in Icelandic Fisheries. In Handbook of Marine Fisheries Conservation and Management; Oxford University Press: Oxford, UK, 2010; pp. 299-309.

82. Palsson, G.; Helgason, A. Figuring fish and measuring men: The individual transferable quota system in the Icelandic cod fishery. Ocean Coast. Manag. 1996, 28, 117-146. [CrossRef]

83. Runolfsson, B.; Arnason, R. Initial Allocation of ITQs in the Icelandic Fisheries. In FAO Fisheries Technical Paper; FAO: Rome, Italy, 2001; pp. 24-31.

84. Eythorsson, E. A decade of ITQ-management in Icelandic fisheries: Consolidation without consensus. Mar. Policy 2000, 24, 483-492. [CrossRef]

85. McCay, B.J. Social and ecological implications of ITQs: An overview. Ocean Coast. Manag. 1995, 28, 3-22. [CrossRef] 
86. Eythórsson, E. Theory and practice of ITQs in Iceland: Privatization of common fishing rights. Mar. Policy 1996, 20, 269-281. [CrossRef]

87. Kokorsch, M.; Karsdottir, A.; Benediktsson, K. Improving or overturning the ITQ system? Views of stakeholders in Icelandic fisheries. Marit. Stud. 2015, 14. [CrossRef]

88. Agnarsson, S.; Matthiasson, T.; Giry, F. Consolidation and distribution of quota holdings in the Icelandic fisheries. Mar. Policy 2016, 72, 263-270. [CrossRef]

89. OECD The political economy of the ITQ system and resource rent tax in Icelandic fisheries. In The Political Economy of Biodiversity Policy Reform; OECD Publishing: Paris, France, 2017.

90. Chambers, C.; Helgadóttir, G.; Carothers, C. "Little kings": Community, change and conflict in Icelandic fisheries. Marit. Stud. 2017, 16. [CrossRef]

91. Edvardsson, K.N.; Cezara, P.; Benediktsson, K. Mapping the geographical consolidation of fishing activities in Iceland during the maturation of the ITQ fi sheries management system. Appl. Geogr. 2018, 97, 85-97. [CrossRef] 